\title{
Penyelesaian Kasus Pelanggaran HAM Berat melalui Pengadilan Nasional dan Internasional serta Komisi Kebenaran dan Rekonsiliasi
}

\author{
Aulia Rosa Nasution * \\ Universitas Medan Area
}

*Corresponding author: E-mail: nasution82auliarosa@gmail.com

\begin{abstract}
Abstrak
Hak Asasi Manusia (HAM) merupakan hak - hak yang dimiliki oleh setiap manusia tanpa memandang perbedaan ras, warna kulit, gender,suku,agama bahasa, jenis kelamin, agama, dan politik. HAM secara hukum dijamin dalam hukum HAM yang melindungi individu-individu atau kelompok dari tindakan-tindakan yang melanggar kebebasan serta harkat dan martabat manusia. Salah satu instrument dari hukum HAM yang digunakan sebagaipedoman bersama dalam melaksanakan norma-norma HAM adalah Deklarasi Universal Hak Asasi Manusia tahun 1948 yang dirumuskan oleh PBB dan ditaati sebagai norma internasional oleh negara-negara di seluruh dunia. Dalam rangka menegakkan HAM pemerintah Indonesia telah mengeluarkan UU No. 39 tentang HAM dan UU No. 26 tahun 2000 tentang Pengadilan HAM. Salah satu persoalan yang masih mengganjal selama bertahun-tahun adalah penyelesaian kasus-kasus pelanggaran HAM di Indonesia. Seiring dengan perkembangan demokrasi, maka salah satu tuntutan yang mendesak di era pemerintahan Jokowi adalah bagaimana upaya perlindungan dan penegakan hukum di dalam menyelesaikan berbagai kasus pelanggaran HAM yang selama ini terbengkalai karena belum adanya keseriusan dan kesungguhan pemerintah untuk menyelesaikan kasus-kasus tersebut. Upaya perlindungan dan penegakan hukum terhadap HAM merupakan salah satu kewajiban Negara terhadap rakyat Indonesia dalam menjamin pelaksanaan hak-hak yang fundamental.
\end{abstract}

Kata kunci : Pelanggaran HAM Berat, Pengadilan Nasional, Pengadilan Internasional, Komisi Kebenaran dan Rekonsiliasi (KKR), Perlindungan HAM , Penegakan Hukum

\begin{abstract}
Human rights are the rights which is possessed by every humanbeing regardless of race, color, gender, ethnicity, religion, language, gender, religion and politics. Human rights are legally guaranteed by human rights law which is protecting the individual or groyps from acts that violate the freedom and the dignity of humanity. One of the human rights law instrument which has been used as a reference in implementing the human rights norms is the Universal Declaration of Human Rights in 1948 which has been formulated by the United Nations and adhered to as an international norm by countries around the world. In order to uphold the human rights, the Indonesian government has passed the law number 39 of 1999 on Human Rights and law number 26 of 2000 on Human Rights Court. One of the problems that still hamper for years are the legal settlements of human rights cases in Indonesia. Along with the development of democracy in Indonesia, one of the urgents issue in Jokowi Presidential Government is the legal settlement and the law enforcement efforts to solve various cases of gross violation of human rights which have been neglected for years due to the government's insufficiency in resolving the cases. The efforts in human rights protection and human rights law enforcement becamea State's obligation to all of the Indonesian people in ensuring the implementation of their fundamental rights
\end{abstract}

Keyword: Gross Violation of Human Rights, National Courts, International Courts, The Truth and Reconciliation Comission, Human Rights Protection, Law Enforcement

How to Cite: Nasution, A.R., (2018), Penyelesaian Kasus Pelanggaran HAM Berat melalui Pengadilan Nasional dan Internasional serta Komisi Kebenaran dan Rekonsiliasi, Mercatoria, 11 (1): 90-126. 


\section{PENDAHULUAN}

Hak Asasi Manusia (HAM) pada hakekatnya merupakan hak kodrati yang secara inheren melekatdalam setiap diri manusia sejak lahir, Pengertian ini mengandung arti bahwa HAM merupakan karunia Tuhan Yang Maha Esa kepada hambanya. Mengingat karena HAM itu adalah karunia Tuhan, maka tidak ada badan apapun yang dapat seorangpun diperkenankan untuk merampasnya serta tidak ada kekuasaan apapun yang boleh membelenggunya. (Bambang Sutiyoso, 2010)

Pengertian HAM pertamakalinya dikemukakan oleh John Locke, yang menjelaskan bahwa hak asasi manusia adalah hak- hak yang diberikan langsung oleh Tuhan Yang Maha Pencipta sebagai sesuatu yang bersifat kodrati. Karena sifatnya yang demikian, maka tidak ada kekuasaan apapun di dunia yang dapat mencabut hak asasi setiap manusia. HAM adalah hak dasar setiap manusia yang dibawa sejak lahir sebagai anugerah Tuhan Yang Maha Esa; bukan pemberian manusia atau lembaga kekuasaan.

Pada akhir abad XIV hingga awal abad XIIV, muncul ide baru John Locke bahwa manusia memiliki hak yang tidak dapat dihilangkan yaitu: life, liberty and prosperity. Sebagai homo sapiens, manusia mempunyai tiga macam hak asasi, yaitu hak untuk hidup, hakatas kebebasan/ kemerdekaan, hak untuk memiliki sesuatu. Bahkan ditekankan lagi bahwa hak untuk memiliki sesuatu (property rights) tidak hanya meliputi barang miliki (estates) tetapi juga kehidupan (lives) dan kebebasan (liberties) bahkan tidak hanya itu melainkan lima macam hak di dalam property rights yaitu nyawa, badan, kemerdekaan, kehormatan dan harta benda (leven, liif, vrijheids, eervermogen) (Max Boli Sabon, 2014). Negara harus melindungi hak-hak tersebut dari tindakan perampasan dan perkosaan.

Dalam perkembangannya muncul J.J. Rosseau dengan teori kontrak sosialnya bahwa munculnya kekuasaan negara itu karena berdasarkan persetujuan atau kontrak antara seluruh anggota masyarakat untuk membentuk suatu pemerintahan. Negara tidak bisa mencabut hak-hak dasar yang dimiliki individu dan masyarakat, bahkan negara harus melindungi hak hak tersebut dari tindakan perampasan dan perkosaan (Reinhart, 1999). Pemikiran John Locke dan Rosseau tentang Hak Asasi Manusia menjadi dasar berkembangnya pemikiran-pemikiran selanjutnya tentang hak asasi manusia, dan berpengaruh besar pada terjadinya revolusi di Perancis dan Amerika Serikat.

Lahirnya hak asasi manusia dalam bentuk peraturan tertulis pertama kali ditemukan dalam Magna Charta 1215 di kerajaan Inggris yang menyebutkan bahwa raja dapat dibatasi kekuasaannya dan dapat dimintai pertanggungjawaban hukum. Dari sini muncul doktrin bahwa tidak ada pihak yang kebal hukum, termasuk raja yang memiliki kekuasaan (Ahmad Kosasih, 2003). Semangat Magna Charta ini menjadi inspirasi munculnya undang undang dalam kerajaan Inggris tahun 1689 yang dikenal dengan undangundang hak (Bill of rights). Munculnya "bill of rights" menjadi awal munculnya dari prinsip "equality before law" atau persamaan di depan hukum yang artinya manusia memiliki kedudukan yang sama dan sederajat di hadapan hukum. Prinsip 
inilah yang menjadi dasar berkembangnya negara hukum dan demokrasi yang menjamin asas persamaan dan kebebasan sebagai warga negara.

Pada tahun 1776 di Amerika Serikat terjadi deklarasi kemerdekaan (declaration of independence) yang $\mathrm{di}$ dalam deklarasi tersebut dinyatakan dengan tegas bahwa manusia adalah merdeka sejak dalam perut ibunya, sehingga dengan tidak masuk akal jika setelah lahir dia harus terbelenggu. Semangat kemerdekaan ini terinsipirasi dari paham Rosseau dan Montesquieu tentang teori pemisahan kekuasaan (trias politica). Teori pemisahan kekuasaan ini menciptakan satu susunan negara yang adil dan seimbang. Demikian juga, Pada tahun 1789 di Perancis lahir sebuah deklarasi yang dikenal dengan "the French Declaration" yang di dalamnya dikemuakan hak-hak yang lebih rinci yang menjadi dasar dari "the rule of law'. Di samping itu, di dalam "the French Declaration"juga diatur mengenai tidak bolehnya penangkapan dan penahanan secara semena mena, prinsip "presumption of innocence", hak kebebasan berpendapat, kebebasan beragama dan perlindungan terhadap hak milik.

Dengan adanya hak-hak asasi manusia yang terinci tersebut dapat dikatakan bahwa Deklarasi Perancis sudah mencakup hak-hak yang menjamin timbulnya negara demokrasi maupun negara hokum (Baharudin Lopa, 1996). Meskipun "the French Declaration" ada setelah "Declaration of independence" di Amerika serikat, Deklarasi Prancis merupakan satu kristalisasi dari revolusi yang panjang dengan tujuan mendapatkan jaminan hak asasi manusia dalam undang-undang negara. Dua tahun kemudian, lahir Trisloganda yang berisi; (1) kemerdekaan (Liberte); (2) kesamaan (equalite); (3) kerukunan dan persaudaraan (fraternite). Tiga prinsip inilah yang kemudian melahirkan konstitusi Prancis tahun 1791 (Ahmad Kosasih, 2003).

Perkembangan berikutnya, hakhak asasi manusia terus menjadi persoalan yang aktual. Hak - hak asasi yang diakui pada masa lampau sudah dianggap tidak mampu lagi memenuhi tuntutan keadaan sosial masyarakat yang terus berkembang. Hak-hak yang pada masa itu berkembang terkesan hanya hak yang bersifat yuridis politik saja, maka pada awal abad ke-XX Presiden Amerika Serikat, Franklin D. Roosevelt merumuskan dan mengeluarkan "the Four Freedoms', yaitu; a) Freedom of speech, b) freedom of religion; c) freedom of fear; $d$ ) freedom from want

Rumusan hak asasi manusia baru ini merupakan hasil pemikiran bahwa untuk dapat hdup dengan nyaman, manusia tidak hanya bisa dibekali dengan hak politik saja tetapi hak atas kebutuhan hidup sehari hari juga harus terpenuhi. The Four Freedoms ini menjadi inspirasi bagi adanya Universal Declaration of Human Rights (UDHR) atau dikenal dengan Deklarasi Universal Umat Manusia (Deklarasi ini memuat 30 Pasal yang sarat dengan hak-hak asasi manusia dalam segala bidang, meliputi bidang politik, yuridis, sosial, ekonomi dan budaya. UDHR sering disebut sebagai Generasi I Hak Asasi Manusia. Dalam perkembangannya, pada tahun 1993 diadakan Konferensi Dunia tentang Hak Asasi Manusia yang dikenal dengan 
Konferensi Wina. Konferensi ini menghasilkan komitmen bersama dalam pelaksanaan perlindngan HAM di seluruh dunia sesuai dengan DUHAM dan instrument lain yang ada kaitannya dengan HAM dan hukum Internasional) yang dikeluarkan oleh Perserikatan Bangsa-Bangsa (PBB) pada tahun 1948.

Terdapat bermacam-macam istilah dalam bahasa asing atau bahasa Indonesia yang digunakan untuk mengungkapkan HAM. Istilah-istilah tersebut antara lain ; "droits de'l homme" (Perancis), "human rights" (Inggris), "meselijek rechten" (Belanda), "civil rights" (AS) yang dapat dijelaskan sebagai hak manusia. Istilah lainnya "basic rights" (Inggris), "grondrechten" (Belanda) yang menunjukkan pengertian Hak Asasi Manusia (Ahmad Kosasih, 2003). HAM juga sering disebut sebagai hak fundamental yang disebut dengan "fundamental rights" (Inggris), "fundamentele rechten" (Belanda). HAM juga dikenal sebagai "constitutional rights" (Inggris) yang berarti hak asasi berdasarkan konstitusi. Namun tidak semua "constitutional rights" adalah hak asasi manusia karena ada juga yang disebut "the Citizen's constitutional rights" yaitu hak rakyat atau hak warga negara yang hanya berlaku bagi warga negara yang bersangkutan; jadi bukan hak asasi yang universal.

Secara etimologis, hak asasi manusia terbentu dari tiga (3) kata yaitu; a) hak, b) asasi; c) manusia. Dua kata pertama, hak dan asasi berasal daribahasa Arab, sementara kata manusia adalah kata dalam bahasa Indonesia. Kata haqq diambil dari kata haqqa, yahiqqu, haqqaan yang berarti benar nyata, pasti, tetap dan wajib. Kata asasi berasal dari kata "assa, yaussu, asasaan " yang berarti asas, pangkal, asal. Dengan demikian asasi artinya segala sesuatu yang bersifat mendasar dan fundamental yang selalu melekat pada objeknya (Mahrus Ali \& Syarif Nurhidayat).

Pengertian hak menurut hukum adalah segala sesatu yang boleh dilakukan dan boleh tidak dilakukan. Artinya terhadap suatu hak, pemilikan hak bebas untuk melaksanakannya atau tidak melaksanakannya. Mochtar Kusumaatmadja dan B. Arief Sidharta menjelaskan bahwa pengertian hak pada dasarnya berintikan kebebasan untuk melakukan atau tidak melakukan sesuatu berkenaan dengan sesuatu atau terhadap subyek hukum tertentu atau semua subyek hukum tanpa halangan atau gangguan dari pihak manapun dan kebebasan tersebut memiliki landasan hukum (diakui atau diberikan oleh hukum) dan karena itu dlindungi oleh hokum (Ahmad Kosasih, 2003).

Menurut Scott Davidson, dalam menegakkan hak asasi terdapat 3(tiga) hal yang perlu mendapat perhatian yaitu; 1) hak hak itu secara kodrati inheren, universal dan tidak dapat dicabut; 2) perlindungan terbaik atas hak hak asasi tersebut hanya pada negara demokrasi; 3) batas batas pelaksanaan hak hanya dapat ditetapkan dan dicabut oleh undangundang (Scott Davidson, 2008).

Di Indonesia, pengaturan tentang HAM telah dimuat di dalam UndangUndang No. 39 tahun 1999 tentang Hak Asasi Manusiayang menjelaskan bahwasanya Hak Asasi Manusia adalah seperangkat hak yang melekat pada hakikat manusia sebagai mahluk Tuhan 
yang Maha Esa dan merupaan anugerahNya yang wajib dihormati, dijunjung tinggi, dan dilindungi oleh negara hukum, pemerintahan dan setiap orang, demi kehormatan serta perlindungan harkat dan martabat manusia (Pasal 1 butir 1 UU No 39 tahun 1999 tentang Hak Asasi Manusia).

Dari rumusan definisi tersebut dapat diketahui bahwa adanya hak asasi manusia semata - mata karena manusia adalah mahluk ciptaan Tuhan yang berbeda dengan mahluk ciptaan lainnya. Hak asasi itu juga ada semata mata karena hadiah tanpa pamrih dari Tuhan agar manusia itu dapat hidup sungguhsungguh sebagai manusia. Oleh karena itu, dalam satu definisi yang sama ditetapkan juga kewajiban asasi, yaitu kewajiban negara hukum, pemerintah, dan setiap orang untuk menghormati, menjunjung tinggi dan melindungi hak asasi orang lain" (Max Boli Sabon).

Berdasarkan pengertian HAM tersebut, jelas bahwa HAM di Indonesia memiliki karakteristik tersendiri, yaitu memiliki sisi teologis yang cukup kuat. Pernyataan bahwa HAM adalah anugerah dari Tuhan yang Maha Esa menunjukkan bahwa HAM adalah suatu pemberian Tuhan yang kemudian melekat pada tiap diri manusia. HAM menjadi tanggungjawab bagi setiap pihak untuk menjaga dan melindunginya, baik negara, hukum, masyarakat maupun tiap individu dimanapun dan kapanpun. Hak Asasi Manusia meliputi hak di bidang sipil, politik, sosial dan ekonomi sampai apda hak untuk hidup dalam lingkungan yang sehat. Pelanggaran terhadap HAM sama saja merendahkan martabat manusia dari kemanusiaannya (Romli Atmasasmita, 2007).

Menurut Krisdyatmiko, hak asasi manusia pada dasarnya dapat dibagi menjadi tiga yaitu; 1) hak klasik berupa hak sipil - politik 2) hak ekonomi dan 3) hak sosial budaya. Sementara itu Sacipto Raharjo membagi generasi HAM menjadi tiga yaitu generasi pertama, yang meliputi hak sipil dan politik, generasi kedua yang meliputi hak sosial, ekonomi dan budaya, dan generasi ketiga yang memuat sejumlah hak-hak kolektif (Sacipto Rahardjo, 2005).

Generasi pertama yaituHak-hak Sipil dan Politik (Sipol) merupakan hak yang dimiliki warga negara ketika berhadapan dengan entitas negara yang memiliki kedaulatan. Hak-hak yang dimiliki warga negara sebagai warga sipil dalam sebuah negara dan juga hak politik warga, yang memiliki kedudukan yang sama dalam pandangan negara, tidak ada diskriminasi dan sebagainya dalam kedudukannya sebagai warga negara maupun sebagai subyek hukum. Hak Sipil dan Politik dikemukakan dalam kovenan internasional tahun 1966 oleh PBB yaitu International Covenant on Civil and Political Rights- ICCPR (Kovenan Internasional tentang Hak-hak Sipil dan Politik). Kovenan tersebut telah diratifikasi oleh Indonesia dan dituangkan ke dalam Undang-undang Nomor 12 Tahun 2005 tentang Hak-hak Sipil dan Politik. Kovenan ini merupakan hasil tarik menarik antara kepentingan Blok Barat dan Blok Timur pasca perang dingin.

Generasi kedua yaitu Hak -hak Ekonomi, Sosial dan Budaya (Ekosob) . Hak - hak Ekonomi, Sosial dan Budaya 
merupakan hak asasi manusia yang merepresentasikan manusia sebagai mahluk yang mampu berkarya dan membutuhkan perangkat tertentu untuk dapat bertahan dalam kelanjutan kehidupannya. Hak ekosob pada dasarnya adalah sebuah kebutuhan tetapi dengan adanya fenomena diskriminasi negara kepada kaum yang lemah dengan alasan untuk kepentingan lebih besar pasca menguatnya rezim ekonomi global, maka hak ekosob yang merupakan kebutuhan pokok dapat menjadi hak untuk diklaim kepada negara.

Hak ekonomi, sosial dan budaya memiliki arti yang sangat penting bagi kehidupan manusia karena beberapa alasan berikut yaitu; a) hak ekosob mencakup berbagai masalah paling utama yang dialami oleh manusia sehari-hari seperti makanan yang cukup, pelayanan kesehatan dan perumahan yang layak sebagai bagian dari kebutuhan pokok (basic necessities) bagi seluruh umat manusia; b) hak ekosob tidak dapat dipisahkan dengan hak asasi manusia yang lainnya; interdependensi hak asasi manusia adalah realitas yang tidak bisa dihindari saat ini; c) hak ekosob mengubah kebutuhan menjadi hak atas dasar keadilan dan martabat manusia. Hak ekosob memungkinkan masyarakat menjadikan kebutuhan pokok mereka sebagai sebuah hak yang harus diklaim (Agung Yudhawiranata, 2016). Hak ekosob ini diatur pertama kali dalam kovenan internasional yaitu International Covenant on Economic, Social and Cultural Rights ICESCR (Kovenan Internasional tentang Hak-hak Ekonomi, Sosial dan Budaya) pada tahun 1966. Indonesia telah meratifikasi kovenan tersebut dan dituangkan dalam Undang-undang Nomor 11 Tahun 2005.

Generasi ketigamuncul seiring dengan pembangunan dan kemajuan dalam suatu negara yang terkadang mengesampingkan dampak-dampak buruk yang diakibatkan dan masyarakat menjadi korban dari semua itu. Hak kolektif meliputi hak atas perkembangan/ kemajuan (development), hak atas perdamaian, hak atas lingkungan yang bersih, dan hak atas kekayaan alam, hak atas warian budaya (Sacipto Rahardjo). Keberadaan hak kolektif ini sebagai reaksi terhadap proses pembangunan dalam suatu negara. Adanya kecenderungan diskriminasi dan tidak adanya pemerataan dalam hal pembangunan ekonomi, dan juga infrastruktur, serta munculnya ketidakadilan dengan mengorbankan sekelompok masyarakat demi pembangunan dan kemajuan kelopok yang lain membuat hak kolektif ini semakin dirasa penting.

Hak kolektif cenderung dilanggar oleh negara yang sedang berkembang dan gencar dalam membangun seperti di Indonesia. Menurut Scott Davidson, munculnya hak generasi ketiga atau hak solidaritas dikaitkan dengan bangkitnya nasionalisme Dunia Ketiga dan persepsi negara-negara berkembang bahwa tatanan internasional yang ada cenderung memusuhi mereka. Hal ini juga dapat dipandang sebagai tuntutan negara-negar berkembang atas perlakuan yang lebih adil (Scott Davidson). Burns Weston telah mengidentifikasi bahwa setidaknya terdapat 6 (enam) kategori hak generasi ketiga antara lain yaitu; (1) hak atas penentuan nasib sendiri di bidang 
Aulia Rosa Nasution, Penyelesaian Kasus Pelanggaran HAM Berat melalui Pengadilan Nasional dan Internasional serta Komisi Kebenaran dan Rekonsiliasi

ekonomi,politik, sosial dan kultural; (2) sosial; (3) hak untuk berpartisipasi dalam dan memperoleh manfaat dari Warisan Bersama Umat Manusia (Common Heritage of Mankind) serta informasi dan kemajuan lain; (4) Hak atas perdamaian; (5) Hak atas lingkungan yang sehat; (6) Hakatas bantuan kemanusiaan (Scott Davidson).

Berbagai kasus pelanggaran HAM dalam proses pembuatan waduk Kedungombo, kerusakan lingkungan di sekitar tambang emas Freeport, relokasi kaum pinggiran dengan tidak diikuti dengan ganti rugi yang memadai, merupakan contoh kecil dari pelanggaran hak kolektif oleh negara. Contoh-contoh kejadian tersebut merupakan bentuk kejahatan terhadap hak kolektif masyarakat berupa kesejahteraan dan kedamaian hidup dalam suasana yang sehat. Salah satu penerapan dari hak kolektif ini dapat ditemukan dalam perundang-undangan yang mengatur tentang hak-hak yang dimiliki oleh masyarakat (Misalnya kita dapat menemukan hak kolektif dalam UU Nomor 23 Tahun 1997 tentang Pengelolaan Lingkungan Hidup , Pasal 37 ayat (1) yang menyatakan; " Masyarakat berhak mengajukan gugatan perwakilan ke pengadilan dan/atau melaporkan ke penegak hukum mengenai berbagai masalah lingkungan hidup yang merugikan perikehidupan masyarakat").

Menurut Hamid Awaluddin, HAM berkembang sampai pada generasi keempat. HAM dalam perspektif ini acapkali diistilahkan dengan "Action plan of human rights". Generasi keempat HAM mulai menggelinding dalam konferensi HAM sedunia di Wina pada tahun 1993 yang dikenal dengan "The Vienna Declaration and Programme of Action"(VDPA). Dalam tahap ini, umat manusia tidak lagi berbicara dalam kerangka tuntutan kejelasan mengenai hak-hak fundamental mereka. HAM dalam generasi kempat ini sudah menuntut level aplikasi di lapangan.

Dalam generasi keempat HAM ini ada empat agenda utama yang selalu mengemuka antara lain yaitu (Hamid Awaluddin, 2012): 1) masalah impuniti; 2) tuntutan agar diperjelas lembagalembaga negara yang secara khusus menangani masalah-masalah HAM sehingga rakyat bisa mengetahui nasib mereka di bidang HAM; 3) terjadinya tuntutan mengenai parameter yang jelas tentang perilaku yang dinilai melanggar HAM; 4) tuntutan mengenai pendidikan HAM sangat menonjol; 5) tuntutan adanya ikhtiar konkret untuk melindungi kelompok-kelompok rentan tertentu dalam masyarakat khususnya kelompokkelompok rentan seperti kaum perempuan, anak-anak, orang tua, penduduk asli, dan sebagianya.

\section{METODE PENELITIAN}

Penelitian hukum merupakan upaya untuk mencari dan menemukan pengetahuan yang benar mengenai hukum. Mencari dan menemukan itu tentu saja ada caranya, yaitu melalui metode (M. Syamsudin, 2007). Dalam penelitian ini menggunakan penelitian normatif, yaitu melakukan kajian terhadap berbagai peraturan perundang-undangan yang berkaitan dengan Penyelesaian Kasus Pelanggaran HAM Berat melalui Pengadilan Nasional dan Internasional serta Komisi Kebenaran dan Rekonsiliasi. Penelitian 
hukum normatif atau penelitian hukum kepustakaan adalah penelitian hukum yang dilakukan dengan cara meneliti bahan pustaka atau bahan sekunder belaka (Soerjono Soekanto dan Sri Mamudji, 2001). Di dalam penelitian hukum normatif, maka penelitian terhadap asas-asas hukum dilakukan terhadap kaidah-kaidah hukum, yang merupakan patokan-patokan berprilaku atau bersikap tidak pantas (Nomensen Sinamo, 2009).

\section{HASIL DAN PEMBAHASAN}

\section{Prinsip-prinsip dalam Hak Asasi Manusia}

Di dalam HAM terdapat empat prinsip dasar HAM yaitu; 1)kebebasan, 2) kemerdekaan, 3) persamaan dan 4) keadilan. Kebebasan merupakan penghormatan yang diciptakan oleh Sang Pencipta kepada martabat manusia selaku ciptaan-Nya dimana manusia diberi kebebasan oleh Tuhan untuk berkuasa. Kemerdekaan memiliki arti bahwa manusia telah diberikan kebebasan oleh Sang Pencipta oleh karena itu manusia harus dibiarkan meredeka dalam arti tidak boleh dijajah, dibelenggu atau dipasung dalam bentuk apapun.

Persamaan memiliki arti bahwa setiap manusia berasal dari produk yang sama sebagai ciptaan Tuhan maka manusia sebagai sesama ciptaan Tuhan tidak boleh membedakan manusia yang satu dengan lainnya. Atas dasar ini maka dirumuskan dalam peraturan perundangundangan bahwa setiap manusia berkedudukan sama di hadapan hukum dan pemerintahan. Prinsip dasar keadilan menunjukkan adanya persamaan di hadapan hukum dan pemerintahan sebagai ciri utama negara hukum dan negara demokrasi. Tujuan utama dari negara hukum dan negara demokrasi adalah menjamin adanya keadilan dan untuk menegakkan keadilan.

Prinsip keadilan ini juga didasarkan pada teori keadilan. Menurut Van Apeldoorn, terdapat dua macam keadilan yaitu keadilan komutatif (kesamaan) dan keadilan distributif (kesebandingan). Keadilan komutatifadalah keadilan yang memberikan jatah kepada setiap orang sama banyak tanpa mengingat jasa-jasa perseorangan. Keadilan distributif, sebaliknya memberikan jatah kepada tiaptiap orang menurut jasanya.

Teori keadilan lainnya yang lebih relevan dengan HAM adalah teori keadilan dari John Rawls. Menurutnya, sekurangkurangnya terdapat tiga prinsip yang mengatur tentang keadilan. Teori keadilan Rawls (John Rawls mengonsepsikan keadilan sebagai fairness yang mengandung asas bahwa orang yang merdeka dan rasional yang berkehendak untuk mengembangkan kepentingankepentingannya hendaknya memperoleh suatu kedudukan yang sama pada saat akan memulainya dan itu merupakan syarat-syarat yang fundamental bagi mereka untuk memasuki perhimpunan yang mereka kehendaki. Dengan pengertian tersebut, menurut Rawls keadilan menjadi fairness (wajar, alamiah) jika tatanan yang ada dapat diterima oleh semua orang secara adil. Lewat penerimaan dengan ikhlas semua tatanan yang ada oleh semua golongan, kelompok, ras, etnik, agama tanpa tekanan, otomatis tatatanan dalam masyarakat menjadi adil) bertujuan untuk memberikan dasar dasar bagi kerja sama sosial dalam masyarakat bangsa yang pluralistik modern. 
Menurutnya, pengaturan masyarakat pluralistik modern tidak boleh didasarkan atas suatu anutan nilai hidup tertetu melainkan haruslah dikendalikan oleh prinsip yang menjamin dan mengekspresikan kepentingan bersama. Prinsip inilah yang disebut dengan keadilan sosial atau "justice as fairness" (Bur Rasuanto, 2005).

Prinsip pertama menyatakan bahwa setiap orang mempunyai hak yang sama atas seluruh sistem kebebasan pokok yang sama seluas-luasnya yang dapat diselaraskan dengan sistem yang sama bagi oranglain. Prinsip kedua menyatakan bahwa ketimpangan (ketidaksamaan sosial) dan ekonomi harus diatur sedemikian rupa agar menghasilkan manfaat seoptimal mungin bagi mereka yang paling kurang (tidak beruntung). Prinsip ketiga, menyediakan suatu sistem akses yang sama untuk semua jabatan dalam kesamaan peluang. Melalui cara berpikir Rawls ini dapat dipahami konsepsi umum tentang keadilan yang "fairness", krn menempatkan aspek kesamaan, baik secara umum (the principle of greatest equal liberty) maupun persamaan kesempatan (the principle affair of opportunity) dan ketimpangan atau ketidaksamaan (the difference principle) secara fair.

\section{Deklarasi Universal Hak-Hak Asasi Manusia (DUHAM)}

Perumusan HAM ke dalam piagam HAM Internasional (Bill of Rights) pada awalnya dilakukan tahun 1946 atas inisiatif Presiden Truman (Presiden Amerika Serikat saat itu), bersama dengan Komisi Hak Asasi Manusia PBB
(Comission of Human Rights-CRR) yang mulai bersidang pada bulan Januari 1947 dengan Komisi Hak Asasi Manusia PBB (Comission of Human Rights-CRR). Setelah hampir dua tahun bekerja hasil kerja Komisi HAM PBB disampaikan kepada PBB. Pada 10 Desember 1948, Sidang Umum PBB di Istana Chaillot, Paris, menerima hasil kerja komisi. Dari perwakilan 58 negara dalam sidang tersebut, 48 negara menyatakan setuju, 8 negara abstain dan 2 negara absen. Atas persetujuan sebagian besar perwakilan negara yang hadir maka dihasilkan "International Bill of Rights" dalam sebuah deklarasi yang disebut dengan Universal Declaraton of Human Rights -UDHR (Deklarasi Universal Hak-hak Asasi Manusia- DUHAM) atau Pernyataan Umum tentang Hak-hak Asasi Manusia.

Sebagai sebuah pernyataan , Piagam PBB baru mengikat secara moral dan belum sepenuhnya yuridis. Meskipun demikian, dokumen tersebut memiliki pengaruh dan kekuatan moril, politik dan pendidikan yang sangat besar yang melambangkan komitmen moril dunia pada norma-norma hak asasi manusia. Hak Asasi Manusia (HAM) secara universal mengalami perkembangan yaitu; (1) Generasi Pertama, HAM Sipil dan Politik; (2) Generasi Kedua, HAM Ekonomi dan Sosial Budaya, (3) Generasi Ketiga, HAM untuk Pembangunan Kolektif yaitu hak - hak negara secara kolektif untuk berpartisipasi dalam pembangunan untuk menikmati hasil-hasil pembangunan dan untuk menentukan nasib sendiri (the rights of self determination) (Endang Sutrisno, 2007).

Adapun tujuan DUHAM antara lain sebagai berikut; a) sebagai tolak ukur 
(standar umum) prestasi bersama semua rakyat dan semua bangsa ; b) sebagai pengumuman resmi kepada semua negara anggota PBB dan semua bangsa agar memajukan dan menjamin pengakuan dan pematuhan hak-hak dan kebebasankebebasan yang termaktub di dalam DUHAM; c) meskipun DUHAM bukanlah sebagai "convention" atau "covenant" (perjanjian internasional) namun semua anggota PBB secara moral berkewajiban untuk menerapkannya (Max Boli Sabon). Menurut DUHAM, terdapat (5) lima jenis hak asasi yang dimiliki oleh setiap individu yaitu; 1) hak personal (hak jaminan kebutuhan pribadi); 2) hak legal (hak jaminan perlindungan hukum); 3) hak sipil dan politik; 4) hak substensi (hak jaminan adanya sumber daya untuk menunjang kehidupan); dan 5) hak ekonomi , sosial dan budaya (A. Ubaedillah \& A.Rozak, 2015).

Pelaksanaan HAM telah diterapkan ke dalam dua instrumen yaitu pertama, kovenan hak-hak sipil dan politik atau International Covenant on Civil and Political Rights (ICCPR) dan kedua, kovenan hak- hak ekonomi, sosial dan budaya atau International Covenant on Economic, Social and Cultural Rights (ICESCR). Kovenan hak-hak sipil dan politik (ICCPR) sebagaimana ditegaskan ke dalam Pasal 3 s.d. Pasal 21 Universal Declaration of Human Rights dapat digolongkan ke dalam 5 kelompok HAM yaitu: a) hak untuk hidup, memperoleh kebebasan dan keselamatan individu; b) hak pribadi (personal rights) yang meliputi kebebasan menyatakan pendapat, kebebasan memeluk agama, kebebasan bergerak dan sebagainya; c) hak untuk mendapatkan perlakuan yang sama di hadapan hukum dan pemerintahan (rights of egal equality); d) hakatas kebebasan berkumpul secara damai (rights of peacefull assembly); e) hak politik (political rights) yaitu hak untuk ikut serta dalam pemerintahan, hak pilih (memilih dan dipilih dalam pemilihan umum) (Max Boli Sabon).

Sementara itu kovenan internasional tentang Hak-hak Ekonomi, Sosial dan Kebudayaan (ICESCR) sebagaimana ditegaskan dalam Pasal 22 s.d. 28 Universal Declaration of Human Rights dapat digolongkan ke dalam 11 (sebelas) kelompok HAM yaitu: a) hak atas pekerjaan (rights to work); b) hak sosial dan kebudayaan (social and cultural rights) yaitu ; a) hak atas pekerjaan (rights to work); b) hak sosial dan kebudayaan (social and cultural rights) yaitu hak untuk memilih pendidikan, mengembangkan kebudayaan dan sebagainyal; c) hak atas upah yang sama untuk pekerjaan yang sama (equal pay and equal work); d) hak mendirikan dan bergabung dalam serikat bekerja (form and join trade unions); e) hak beristirahat dan berlibur (rest and pleasure); f) hak atas taraf hidup yang memadai untuk kesehatan dan kesejahteraan dirinya termasuk hak atas sandang, pangan, papan serta perawatan kesehatan; g) hak atas pendidikan bagi kaum ibu dan anakanak ; h) hak atas pendidikan, hak prioritas orangtua untuk memilih jenis pendidikan bagi anak-anaknya; i) hak turut serta dalam kehidupan budaya masyarakatnya; j) hak perlindungan atas keuntungan-keuntungan moral dan material yang diperoleh sebagai hasil karya ilmiah, kesusasteraan atau kesenian yang diciptakan; k) hak atas 
Aulia Rosa Nasution, Penyelesaian Kasus Pelanggaran HAM Berat melalui Pengadilan Nasional dan Internasional serta Komisi Kebenaran dan Rekonsiliasi

tatanan sosial dan internasional, tempat hak-hak dan kebebasan-kebebasan yang termaktub dalam Universal Declaration of Human Rights tanggal 10 Desember agar dapat dilaksanakan sepenuhnya (A. Ubaedillah \& A.Rozak, 2015).

\section{Perkembangan Pemikiran HAM di Indonesia}

Wacana HAM di Indonesia telah berlangsung seiring dengan berdirinya Negara Kesatuan Republik Indonesia (NKRI). Secara garis besar perkembangan pemikiran HAM di Indonesia dapat dibagi ke dalam dua periode yaitu periode sebelum dan sesudah kemerdekaan. Pemikiran HAM dalam periode sebelum kemerdekaan dapat dilihat dalam sejarah kemunculan organisasi pergerakan nasional, seperti Boedi Oetomo (1908) Sarekat Islam (1911), Indische Partij (1912), Partai Komunis Indonesia (1920), Perhimpunan Indonesia (1925) dan Partai Nasional Indonesia (1927). Lahirnya organisasi-organisasi pergerakan nasional tersebut tidak bisa dilepaskan dari sejarah pelanggaran HAM yang dilakukan oleh penguasa kolonial, penjajahan dan pemerasan terhadap hak-hak masyarakat Indonesia. Puncak perdebatan HAM yang dilontarkan oleh para tokoh pergerakan nasional seperti Soekarno, Agus Salim, Mohamad Natsir, Mohammad Yamin, K.H. Mas Mansur, K.H. Wachid Hasyim, Mr. Maramis terjadi dalam siding-sidang BPUPKI .

Dalam sidang BPUPKI tersebut para tokoh nasional berdebat dan berunding merumuskan dasar-dasar ketatanegaraan dan kelengkapan negara yang menjamin hak dan kewajiban negara dan warga negara dalam negara RI yang hendak diproklamirkan.Satu hal yang menarik bahwa meskipun UUD 1945 adlah hukum dasr tertulis yang di dalamnya memuat hak-hak dasar manusia Indonesia serta kewajibankewajiban yang bersifat dasar pula, tetapi istilah perkataan HAM itu sendiri tidak dijumpai dalam UUD 1945, baik dalam Pembukaan, Batang Tubuh maupun Penjelasannya karena yang ada hanyalah hak dan kewajiban warga Negara (Majda El Muhtaj, 2005). Pemikiran HAM pada periode awal pasca kemerdekaan masih menekankan pada wacana hak untuk merdeka, hak kebebasan untuk berserikat melalui organisasi politik yang didirikan serta hak kebebasan untuk menyampaikan pendapat terutama di parlemen.

Pemikiran HAM pada periode 1950-1959 (masa demokrasi parlementer) memasuki masa yang sangat kondusif bagi sejarah perjalanan HAM di Indonesia. Menurut catatan Bagir Manan, masa gemilang sejarah HAM di Indonesia pada masa ini tercermin pada 5 (lima) indikator HAM yaitu; a) munculnya partai-partai politik dengan beragam ideologi; b) adanya kebebasan pers; c) pelaksanaan pemilihan umum secara aman, bebas dan demokratis; d) Kontrol parlemen atas eksekutif; e) Perdebatan HAM secara bebas dan demokratis. Berbagai partai politik yang berbeda haluan dan ideologi sepakat tentang substansi HAM Universal dan pentingnya HAM masuk ke dalam UUD 1945.

Selanjutnya pemikiran HAM memasuki periode 1959-1966 melalui sistem demokrasi terpimpin yang terpusat pada kekuasaan Presiden Soekarno. Demokrasi Terpimpin (Guided Democracy) tidak lain sebagai bentuk penolakan 
Presiden Soekarno terhadap sistem Demokrasi Parlementer yang dinilainya sebagai produk Barat. Menurut Soekarno, Demokrasi Parlementer tidak sesuai dengan karakter bangsa Indonesia yang telah memiliki tradisinya sendiri dalam kehidupan bermasyarakat, berbangsa dan bernegara. Melalui sistem demokrasi terpimpin, kekuasaan terpusat di tangan Presiden. Presiden tidak dapat dikontrol oleh parlemen, sebaliknya parlemen dikendalikan oleh presiden. Kekuasaan Presiden Soekarno bersifat absolut, bahkan dinobatkan sebagai Presiden RI seumur hidup. Akibat langsung dari model pemerintahan yang sangat individual ini adalah pemasungan terhadap hak-hak asasi warga negara. Semua pandangan politik masyarakat diarahkan harus sejalan dengan kebijakan pemerintah yang otoriter.

Pada masa 1966-1998, periode pemikiran HAM memasuki masa kepeimpinan Orde Baru. Orde Baru pada awalnya menjanjikan harapan baru bagi penegakan HAM di Indonesia. Berbagai seminar tentang HAM dilakukan oleh Orde Baru. Namun kenyataannya, Orde Baru telah menorehkan sejarah hitam pelanggaran HAM di Indonesia. Pelanggaran HAM Orde Baru dapat dilihat dari kebijakan politik Orde Baru yang bersifat sentralistik dan anti segala gerakan politik yang berbeda dengan pemerintah. Di antara butir penolakan pemerintah Orde Baru terhadap konsep universal HAM adalah: a) HAM adalah produk pemikiran Barat yang tidak sesuai dengan nilai nilai luhur budaya bangsa yang tercermin dalam Pancasila; b) Bangsa Indonesia sudah terlebih dahulu mengenal HAM sebagaimana tertuang dalam rumusan UUD 1945 yang lahir lebih dahulu dibandingkan Deklarasi Universal HAM; c) Isu HAM seringkali digunakan oleh negara-negara Barat untuk memojokkan negara yang berkembang seperti Indonesia.

Pada masa pemerintahan Presiden Soeharto, di era Orde Baru tidak dikenal istilah partai oposisi bahkan sejumlah gerakan yang berlawanan dengan kebijakan pemerintah dinilai sebagai anti pembangunan bahkan anti- Pancasila. Melalui pendekatan keamanan (security approach) dengan cara cara kekerasan yang berlawanan dengan prinsip-prinsip HAM, pemerintah Orde Baru tidak segansegan menumpas segala bentuk aspirasi masyarakat yang dinilai berlawanan dengan pemerintahan Orde Baru. Inilah yang menyebabkan pada masa ini, banyak bermunculan berbagai kasus pelanggaran HAM seperti kasus Tanjung Priok, Kedung Ombo, Lampung, dan Aceh yang merupakan segelintir dari dafter pelanggaran HAM yang pernah dilakukan oleh penguasa Orde Baru.

Upaya penegakan HAM oleh kelompok-kelompok non-pemerintah melalui Lembaga Swadaya Masyarakat (LSM) membuahkan hasil yang menggembirakan. Akibat kuatnya tuntutan penegakan HAM dari kalangan masyarakat akhirnya mengubah pendirian pemerintah Orde Baru untuk bersikap lebih akomodatif terhadap tuntutan HAM. Satu di antara sikap akomodatif pemerintah tercermin dalam persetujuan pemerintah terhadap pembentukan Komisi Nasional Hak Asasi Manusia (Komnas HAM) melalui Keputusan Presiden (Keppres). Kehadiran Komnas HAM adalah untuk memantau dan 
Aulia Rosa Nasution, Penyelesaian Kasus Pelanggaran HAM Berat melalui Pengadilan Nasional dan Internasional serta Komisi Kebenaran dan Rekonsiliasi

menyelidiki pelaksanaan HAM, memberi pendapat, pertimbangan dan saran kepada pemerintah perihal pelaksanaan HAM. Lembaga ini juga membantu pengembangan dan pelaksanaan HAM yang sesuai dengan Pancasila dan UUD 1945.

Meskipun telah dibentuk Komnas HAM namun komitmen Orde Baru untuk melaksanakan HAM secara murni dan konsekuen masih jauh dari harapan masyarakat, bahkan masa pemerintahan Orde Baru sarat dengan pelanggaran HAM yang dilakukan oleh aparat negara atas warga negara. Hal inilah yang menyebabkan kuatnya tuntutan terhadap Presiden Soeharto untuk mundur dari tampuk kepresidenan yang disuarakan oleh kelompok reformis dan mahasiswa pada tahun 1998 melalu isu - isu pelanggaran HAM dan penyalahgunaan kekuasaan dalam berbagai tuntutan reformasi yang disuarakan oleh pelopor reformasi Dr. Amin Rais, tokoh intelektual muslim Indonesia yang sangat kritis terhadap kebijakan pemerintah Orde Baru.

Tahun 1998 merupakan salah satu era terpenting dalam sejarah HAM di Indonesia yang ditandai dengan lengsernya tampuk kekuasaan Orde Baru sekaligus menandai berakhirnya rezim militer di Indonesai dan datangnya era demokrasi dan HAM, setelah selama kurang lebih 30 (tigapuluh) tahun lamanya terpasung di bawah rezim otoriter. Pada masa ini, kepemimpinan Presiden Soeharto digantikan oleh B. J. Habibie yang saat itu menjabat sebagai Wakil Presiden RI. Menyusul berakhirnya pemerintahan Orde Baru, pengkajian terhadap kebijakan pemerintah Orde Baru yang bertentangan dengan prinsip-prinsip HAM dalam kehidupan ketatanegaraan dan kemasyarakatan. Tak kalah penting dari perubahan perundangan, pemerintah di era reformasi ini juga melakukan ratifikasi terhadap sejumlah instrument HAM Internasional untuk mendukung pelaksanaan HAM di Indonesia.

Pasca jatuhnya rezim Soeharto pada Mei 1998, hal ini telah membuka babak baru perjuangan penegakan HAM di Indonesia setelah terpasung selama hampir tiga puluh tahun. Momentum kejatuhan rezim otoritarian ini memunculkan desakan terbuka dari kekuatan pro-demokrasi terhadap rezim sesudahnya (era kepemimpinan B. J. Habibie, Gus Dur, Megawati, SBY dan Jokowi) untuk melakukan langkahlangkah hukum dan politik yang tegas, jelas dan terarah bagi perlindungan HAM di Indonesia khususnya penyeleasian pelanggaran berat HAM di masa lalu (Suparman Marzuki, 2012).

Adapun mandat yang dibebankan kepada pemerintahan era reformasi adalah menyelesaikan Pelanggaran HAM yang berat pada masa lalu yang terjadi di era Orde Baru. Mandat tersebut tertuang dalam TAP MPR No. V/MPR/2000 dan UU No. 26 Tahun 2000 tentang Pengadilan HAM. Di dalam UU No. 26 Tahun 2000 disediakan dua jalan (avenue) yaitu: pertama, melalui pengadilan HAM ad hoc , kedua, melalui Komisi Kebenaran dan Rekonsiliasi (KKR) sebagaimana yang dijelaskan dalam Pasal 43 UU No. 26 Tahun 2000 tentang Pengadilan HAM yaitu; (1) Pelanggaran HAM yang berat yang terjadi sebelum diundangkannya undang-undang ini diperiksa dan diputus oleh Pengadilan HAM ad hoc; 
Pengadilan HAM ad hoc sebagaimana dimaksud dalam ayat (1) dibentuk atas usul Dewan Perwakilan Rakyat Republik Indonesia berdasarkan peristiwa tertentu dengan Keputusan Presiden; Pengadilan HAM ad hoc sebagaimana dimaksud dalam ayat (1) berada di lingkungan Peradilan Umum.

Selanjutnya Pasal 47 UU No. 26 Tahun 2000 tentang Pengadilan HAM menjelaskan yaitu; (1) Pelanggaran HAM yang berat yang terjadi sebelum berlakunya undang-undang ini tidak menutup kemungkinan penyelesaiannya dilakukan oleh Komisi Kebenaran dan Rekonsiliasi; (2) Komisi Kebenaran dan Rekonsiliasi sebagaimana dimaksud dalam ayat (1) dibentuk dengan undangundang (Penjelasan Pasal 43 dan 47 menerangkan: "Ketentuan dalam Pasal ini dimaksudkan untuk memberikan alternatif penyelesaian pelanggaran HAM yang berat yang dilakukan di luar Pengadilan HAM").

Kesungguhan

pemerintahan

B.J.Habibie dalam perbaikan pelaksanaan HAM ditunjukkan dengan pencanangan program HAM yang dikenal dengan istilah Rencana Aksi Nasional HAM (RANHAM) pada pada 25 Juni 1998 yang ditetapkan oleh Keppres No. 129 Tahun 1998 pada 15 Agustus $1998 . \quad$ Agenda ini bersandarkan pada empat pilar yaitu; (1) Persiapan pengesahan perangkat Internasional di bidang HAM; (2) Diseminasi informasi dan pendidikan bidang HAM; (3) Penentuan skala prioritas pelaksanaan HAM; (4) Pelaksanaan isu perangkat Internasional di bidang HAM yang telah diratifikasi melalui perundangundangan nasional (A. Ubaedillah \& Abdul Rozak, 2015).
Substansi Pasal 43 dan 47 tersebut di atas adalah Pelanggaran HAM yang berat yang terjadi sebelum adanya UU Pengadilan HAM dapat diselesaikan melalui Pengadilan HAM ad hoc atau melalui KKR. Inilah politik hukum HAM transisional atau dalam konsep Moh. Mahfud MD disebut dengan politik hukum HAM jangka pendek yang dibuat oleh pemerintahan Pasca OrdeBaru guna menyelesaikan pelanggaran HAM yang berat yang terjadi pada masa rezim terdahulu.

Namun sayangnya, meskipun pengadilan HAM ad hoc telah dilakukan terhadap Pelanggaran HAM yang berat di Timor Timur dan Tanjung Priok, kedua pengadilan HAM ad hoc tersebut berakhir mengecewakan dan hanya menjadi pengadilan pura - pura (sham prosecution) hanya sekedar mekanisme yang diadakan untuk memenuhi tuntutan nasional dan internasional serta memanfaatkan klausul pengutamaan pengadilan domestik atas pengadilan Internasional, dimana dalam pengadilan ini semua pelaku dibebaskan, baik di tingkat Pengadilan Negeri, Pengadilan Banding, Pengadilan Kasasi maupun Pengadilan Peninjauan Kembali (KP), yang pelakunya juga dibebaskan seperti Eurico Gueteres.

Salah satu penyebab mengapa sulit dilakukan peradilan terhadap pelanggaran HAM berat seperti yang telah dialami oleh negara negara di Afrika, Amerika Latin, Eropa Timur dan Asia, karena pelanggaran HAM melibatkan rezim pemerintahan yang berkuasa dalam waktu yang sangat panjang, sehingga hal ini menjadi kendala di dalam proses peradilan. Kesulitan tersebut antara lain: a) kesulitan pembuktian jika penyekesaian 
akan dilakukan melalui jalur hukum (pengadilan) atau disebut kesulitan teknis prosedural ; b) adanya hadangan kekuatan politik pendukung rezim terdahulu, terutama militer atau disebut kendala politis; c) tantangan dari kelompok masyarakat tertentu termasuk sebagian korban atau keluarga korban yang tidak menginginkan mengungkit kembali kasus masa lalu, dengan alasan hanya membuka luka lama. Contoh sebagian para korban dan keluarga korban Tanjung Priok, termasuk kasus kasus lain yang belum memasuki proses hukum seperti kasus Talangsari Lampung, tidak menghendaki kasus itu diungkit kembali. Mereka cenderung memilih untuk melupakan, melihat ke depan dan tidak lagi menoleh ke belakang (Suparman Marzuki).

Kesulitan pembuktian atau teknis prosedural pada kejahatan HAM merupakan sesuatu yang sudah lazim terjadi pada kasus-kasus pelanggaran HAM karena kejahatan itu bukan kejahatan biasa (konvensional) tetapi kejahatan politik atau kejahatan dengan motif politik dari sebuah rezim yang dilakukan secara terencana, rahasia dan sistematis, termasuk dalam menghilangkan jejak kejahatannya. Selain itu lamanya jarak waktu antara terjadiya peristiwa denagn pengusutan berakibat pada sulitnya mencari alat bukti yang rusak, hilang, daya ingat saksi yang berkurang atau bahkan hilang, dihilangkan atau meninggal dunia. Sementara itu kendala politik berupa tekanan, intimidasi , pengaruh dan ancaman kekuatan politik rezim lama menjadi masalah yang umumnya akan mempengaruhi rezim baru.
Rezim pengganti akan dihantui oleh ketakutan pada militer yang akan melakukan kudeta, dan mengembalikan ke rezm otoritarian baru atau melakukan tindakan tindakan liar yang dimaksudkan untuk mengacaukan tatanan sosial, ekonomi , hukum dan politik yang sedang dibangun. Potensi kekuatan rezim lama untuk mencegah rezim baru untuk dapat melakukan langkah-langkah hukum mengusut kejahatan HAM yang pernah mereka lakukan tidak dapat diabaikan karena kekuatan mereka terletak pada pengaruh politik mereka yang kuat .

Di Parlemen sebagaimana yang pernah terjadi, pada periode 1999-2004, Golkar dan TNI-Polri masih merupakan kekuatan politik riil di Parlemen karena dengan 120 kursi, ditambah 62 kursi dari utusan daerah, ditambah 38 kursi TNI Polri jelas memiliki pengaruh politik yang signifikan dalam parlemen. Sementara itu, unsur PNS dan keluarga besarnya sejak Pemilu 1971 menjadi kekuatan besar bagi Golkar dan ini diakui oleh Akbar Tanjung sebagai salah satu penentu kemenangan Golkar pada pemilu-pemilu Orde Baru.

Kekuatan rezim Orde Lama tidak hanya terletak pada pengaruh politik dan eksekutif (birokrasi sipil) atau lembaga yudikatif tetapi juga pada kekuatan ekonomi dan ideologis. Melalui dua unsur utama pendukung Status Quo Orde Baru tersebut upaya blokade atau penghambatan terhadap penyelesaian hukum atas kasus-kasus masa lalu bisa mereka lakukan dengan pelbagai cara, mulai pemandulan aturan hukum material dan formal, mengacaukan opini publik dengan memanipulasi informasi melalui media massa, sampai pada 
tindkaan tindakan fisik berupa penculikan, pembunuhan atau kekacauan.

Kegagalan pengadilan HAM ad hoc meminta pertanggungjawaban hukum pidana pelanggaran HAM, lambannya pembentukan UU KKR, yang kemudian berujung pembatalan UU tersebut oleh MK merupakan keberhasilan rezim lama dalam mengamankan kejahatannya. Rangkaian kegagalan itu sekaligus kegagalan politik hukum HAM transisional yang dimasudkan mengantarkan rezim baru menuju negara hukum demokratis di atas terbangunnya politik hukum HAM bagi penghormatan, perlindungan dan penegakan HAM.

Komitmen pemerintah RI terhadap penegakan HAM tidak hanya ditunjukkan dengan pengesahan UU tentang HAM, yaitu UU No. 39 tahun 1999 dan UU No. 26 tahun 2006 tentang Pengadilan HAM, pembentukan Kantor Menteri Negara Urusan HAM yang kemudian digabung dengan Departemen Hukum dan Perundang-undangan menjadi Departemen Kehakiman dan HAM, penambahan pasal-pasal khusus tentang HAM dalam Amandemen UUD 195, penerbitan inpres tentang pengarusutamaan gender dalam pembangunan nasional, pengesahan UU tentang Pengadilan HAM.

Pada tahun 2001 Indonesia juga menandatangani dua Protokol Hak Anak yaituprotokol yang terkait dengan larangan perdagangan, prostitusi dan pornografi anak serta protokol yang terkait dengan keterlibatan anak dalam konflik bersenjata. Menyusul kemudian pada tahun yang sama pemerintah membuat beberapa pengesahan UU diantaranya tentang perlindungan anak, pengesahan tentang penghapusan kekerasan dalam rumah tangga dan penerbitan keppress tentang Rencana Aksi Nasional (RAN) HAM Indonesia tahun 2004-2009 (A. Ubaedillah \& A.Rozak, 2015).

Politik hukum HAM terus berlanjut dengan diberlakukannya UU No. 39 tahun 1999 tentang HAM sebagai implementasi TAP XVII/MPR/1998. Selanjutnya di era pemerintahan Gus Dur , pemerintah mengeluarkan UU No. 26 tahun 2000 tentang Pengadilan HAM yang memuat ketentuan prinsip retroaktif sehingga memungkikan dilakukannya proses hukum terhadap berbagai kasus pelanggaran berat HAM yang terjadi pada masa lalu. Atas dasar itulah maka pemerintahan Gus Dur membentuk Pengadilan HAM ad hoc di Jakarta, Surabaya, Medan dan Makassar melalui Keppres No. 31 Tahun 2001 untuk mengadili pelanggaran HAM yang terjadi di Timor-Timur dan Tanjung Priok (Suparman Marzuki).

$$
\text { Kebijakan hukum HAM }
$$

pemerintahan era reformasi untuk menyelesaikan pelanggaran HAM pada masa lalu merupakan salah satu kemajuan dalam perkembangan HAM di Indonesia sekaligus menjadi langkah politik hukum HAM yang strategis . Bagi kelompok pro demokrasi, penyelesaian melalui mekanisme hukum dalam bentuk mengadili pelaku merupakan pilihan yang tepat untuk menghilangkan kekebalan hukum (impunity) atau "perlakuan istimewa" terhadap para pemimpin negara dan aparat negara tingkat tinggi yang melanggar HAM di masa lalu. Keberadaan pengadilan HAM juga penting untuk menunjukan supremasi nilai-nilai, 
Aulia Rosa Nasution, Penyelesaian Kasus Pelanggaran HAM Berat melalui Pengadilan Nasional dan Internasional serta Komisi Kebenaran dan Rekonsiliasi

asas-asas dan norma-norma negara hukum dan demokrasi. Kegagalan mengadili dapat menyebabkan ketidakpercayaan rakyat terhadap sistem politik yang dibangun oleh pemerintah sehingga tidak mencerminkan pelaksanaan demokrasi yang sesungguhnya di Indonesia.

Salah satu masalah utama yang menjadi batu ganjalan di dalam upaya penyelesaian kasus pelanggaran HAM masa lalu adalah persoalan apakah kasus kasus tersebut dapat diselesaikan dengan mekanisme formal, prosedural, dan normatif. Kekhawatiran ini beralasan karena telah terbukti terjadi di banyak negara negara di Eropa maupun Asia yang mengalami masa transisional, penggunaan mekanisme hukum di dalam menyelidiki dan mengadili kejahatan HAM masa lalu yang pelakunya kebanyakan dari kalangan militer memang tidak mudah. Itulah sebabnya TAP MPR No. V/MPR/2000 Bab $\mathrm{V}$ angka 3 dan UU No. 26 TAhun 2000 tentang Pengadilan HAM Pasal 47 beserta penjelasannya sudah menyediakan alternatif berupa mekanisme Komisi Kebenaran dan Rekonsiliasi ( KKR) yang kemudian diatur dalam UU No. 27 Tahun 2004, tetapi belum sempat digunakan karena terlanjur dibatalkan oleh Mahkamah Konstitusi (MK) (Suparman Marzuki). Padahal seyogyanya, mekanisme KKR ini diharapkan dapat mengungkapkan kebenaran (telling truths) dan sebagai upaya penyembuhan (healing) atas berbagai pelanggaran HAM yang pernah terjadi pada masa lampau sehingga berbagai kasus pelanggaran HAM dapat dibongkar dan para korban kasus pelanggaran HAM berat dapat terobati.
Selanjutnya komitmen pemerintah Indonesia terhadap penegakan HAM juga ditunjukkan dengan memasukkan pasalpasal yang mengatur tentang HAM seperti yang tertuang dalam Pasal 28 A sampai 28 J dalam Amandemen I sampai V UUD 1945 sehingga hal ini menunjukkan bahwa HAM sudah menjadi bagian dan komitmen dari bangsa Indonesia. Hal ini juga dipertegas dengan dibentuknya UU tentang HAM yaitu UU No. 39 tahun 1999 tentang Hak Asasi Manusia dan UU No. 26 tahun 2006 tentang Pengadilan Hak Asasi Manusia untuk mengadili berbagai kasus pelanggaran HAM (Endang Sutrisno).

Pada Ketetapan MPR No. IV/MPR/1999 tentang Garis-garis Besar Haluan Negara (GBHN) khususnya Bab IV tentang kebijakan, sub bab A tentang hukum, terdapat sekurang-kurangnya empat butir yang mengatur tentang HAM yaitu; (1) menegakkan hukum secara konsisten untuk lebih menjamin kepastian hukum, keadilan dan kebenaran, supremasi hukum serta menghargai HAM; (2) melanjutkan ratifikasi konvensi HAM Internasional sesuai kebutuhan dan kepentingan bangsa dalam bentuk UU; (3) meningkatkan pemahaman, penyadaran, perlindungan, penghormatan dan penegakan HAM dalam seluruh aspek kehidupan; (4) menyelesaikan berbagai proses peradilan terhadap pelanggaran HAM yang belum ditangani secara tuntas.

Penegakan hukum HAM untuk menyelesaikan pelanggaran HAM yang berat pada masa lalu melalui pengadilan dalam pengalaman banyak negara pada umumnya terkendala oleh sulitnya mencari alat bukti dan saksi karena kasusnya telah melampaui waktu yang relatif lama, tidak bisa menjangkau kasus 
dalam jumlah besar, memakan waktu lama dan berlarut-larut, berpotensi gagal akibat kegagalan memenuhi syarat-syarat hukum formal dari proses hukum itu sendiri serta tidak objektif akibat cara berpikir dan menilai dari aparatur penegak hukum terhadap kasus terkontaminasi oleh rezim sebelumnya (Suparman Marzuki). Penegakan hukum terhadap kasus pelanggaran HAM berat di masa lampau juga cenderung bersifat normatif (legalistis) hanya mengacu pada terpenuhinya unsur materil tindakan serta prosedur dan mekanisme hukum tanpa menghiraukan adanya aspek-aspek sosial, moral, politik , kultural dan manusia sebagai pelaksana hukum sehingga menjadi kendala di dalam penyelesaian pelanggaran HAM berat di masa lalu.

\section{Mekanisme Penyelesaian Kasus} Pelanggaran HAM Berat di Indonesia

Hingga saat ini tidak terdapat pengertian tunggal mengenai konsep pelanggaran HAM sekalipun di kalangan para ahli terdapat semacam kesepakatan umum bahwa pelanggaran HAM dimaknai sebagai"pelanggaran terhadap kewajiban negara yang lahir dari instrumentinstrumen internasional HAM". Pelanggaran terhadap kewajiban negara itu dapat dilakukan dengan perbuatannya sendiri (acts of commission) ataupun karena kelalaiannya sendiri (acts of omission). Dalam rumusan lain, pelanggaran HAM adalah "tindakan atau kelalaian oleh negara terhadap norma yang belum dipidana dalam hukum pidana Internasional tetapi merupakan norma HAM yang diakui secara Internasional" (C. de Rover, 2000).
Dari rumusan di atas terlihat bahwa pihak yang bertanggung jawab adalah negara, bukan individu atau badan hukum lainnya. Hal yang menjadi titik tekan dalam pelanggaran HAM adalah tanggung jawab negara (state responsibility). Konsep tanggungjawab negara dalam hukum Internasional biasanya dipahami sebagai "tanggung jawab yang timbul akibat pelanggaran hukum internasional oleh negara". Akan tetapi dalam kaitannya dengan hukum HAM Internasional, pengertian tanggung jawab negara bergeser maknanya menjadi " tanggung jawab yang timbul akibat dari pelanggaran terhadap kewajiban untuk melindungi dan menghormati HAM oleh negara". Kewajiban yang dimaksud itu adalah kewajiban yang lahir dari perjanjian-perjanjian internasional HAM ataupun dari hukum kebiasaan internasional (International Customary Law) khususnya norma-norma hukum kebiasaan internasional yang memiliki sifat "jus cogens".

Rumusan pelanggaran HAM tersebut tidak identik dengan "kejahatan internasional paling serius atau "the most serious international crimes". Meskipun kejahatan internasional seperti genosida, kejahatan terhadap kemanusiaan, agresi, terorisme dan kejahatan perang bisa disebut sebagai "pelanggaran HAM" ia tidak dapat begitu saja disamakan dengan pelanggaran HAM sebab pertanggungjawabannya sangat berbeda (Suparman Marzuki).

Definisi dari pelanggaran HAM telah tertuang di dalam Pasal 1 butir 6 UU No. 39 tahun 1999 tentang HAM yang menjelaskan bahwa Pelanggaran HAM adalah setiap perbuatan seseorang atau 
kelompok orang termasuk aparat Negara baik disengaja maupun tidak disengaja atau kelalaian yang secara melawan hak hukum, mengurangi, menghalangi, membatasi, dan atau mencabut hak asasi manusia seseorang atau kelompok orang yang dijamin oleh Undang-Undang ini, dan tidak mendapat, atau dikhawatirkan tidak akan memperoleh penyelesaian hukum yang adil dan benar, berdasarkan mekanisme hukum yang berlaku".

Rumusan tentang pelanggaran HAM tersebut di atas menurut Titon Slamet kurang tepat karena secara teoretis tidak mengacu pada konsep normatif HAM yang melihat faktor kekuasaan negara sebagai masalah. Konsep HAM secara normatif bertujuan untuk mencegah kemungkinan terjadinya penyalahgunaan wewenang dan kekuasaan koersif negara. Dengan mengaitkan pelanggaran HAM dan kekuasaan negara maka terdapat dua jenis pelanggaran HAM yaitu dengan tindakan action/commission) dan pendiaman (omission) yang ketika pelanggaran dilakukan oleh individu atau kelompok orang yang bukan aparat negara namun negara melalui aparat negara tidak bertindak, baik preventif maupun represif (Suparman Marzuki).

Dalam satu pertemuan dari para 30 ahli yang diselenggarakan di Maastricht pada 22-26 Januari 1997 dan menghasilkan "Maastricht Guidelines" sebagai pedoman untuk mengelaborasi prinsip prinsip Limburg tentang implementasi Kovenan Internasional tentang Hak Ekonomi, Sosial, dan Budaya sebagai sifat dan lingkup pelanggaran hak hak Ekonomi, Sosial dan Budaya, menjelaskan bahwa pelanggaran hak asasi bagi pelaku negara (state actors) atau non negara (non state actors) dapat terjadi melalui tindakan untuk melakukan (acts of comission) oleh negara atau pihak lain yang tidak diatur secara memadai oleh negara atau tidak melakukan tindakan apa pun (acts of commission) oleh Negara (Suparman Marzuki).

Pelanggaran HAM oleh negara, baik yang bersifat "acts of omission" maupun "acts of commission", dapat dilihat melalui kegagalan memenuhi 3 (tiga) kewajiban yang berbeda yaitu sebagai berikut:

1. Kewajiban untuk menghormati. Kewajiban ini menuntut negara , organ dan aparat negara untuk tidak bertindak apapun yang melanggar integritas individu atau kelompok atau pelanggaran pada kebebasan mereka seperti ; (a) pembunuhan di luar hukum; b) penahanan serampangan; c) pelarangan serikat buruh; d) pembatasan terhadap praktik agama tertentu.;

2. Kewajian untuk melindungi. Kewajiban ini menuntut negara dan aparatnya untuk melakukan tindakan yang memadai guna melindungi pelanggaran hak hal individu atau kelompok termasuk pencegahan atau pelanggaran atas penikmat kebebasan mereka. Contoh jenis pelanggaran ini adalah "acts of commission" dalam bentuk ; (a) kegagalan untuk bertindak, ketika satu kelompok etnis tertentu menyerang kelompok etinis tertentu lainnya; (b) kegagalan untuk memaksa perusahaan untuk membayar upah yang tepat 
3. Kewajian untuk memenuhi. Kewajiban ini menuntut negara untuk melakukan tindakan yang memadai, guna menjamin setiap orang di dalam peluang yurisdiksinya untuk memberi kepuasan kepada mereka yang memerlukan, yang telah dikenal di dalam instrument hak asasi dan tidak dapat dipenuhi oleh upaya pribadi. Contoh jenis ini adalah acts of omission seperti ; (a) kegagalan untuk memenuh sistem perawatan kesehatan dasar; (b) kegagalan untuk mengimplementasikan satu sistem pendidikan gratis pada tingkat primer

Satuan-satuan (entitas) bukan pemerintah juga bisa menjadi pelaku pelanggaran Hak Asasi Manusia sebagaimana yang dilakukan oleh Negara atau agen-agen Negara yang bertentangan dengan kewajiban untuk menghormati kebebasan individual atau kelompok. Contoh tindakan oleh satuan bukan negara yaitu; a) pembunuhan penduduk sipil oleh tentara pemberontakan;b) pengusiran komunitas yang dilakukan oleh perusahaan transnasional; c) serangan bersenjata oleh salah satu pihak melawan pihak lain; d) serangan fisik mendadak oleh pengawal pribadi melawan para pemrotes.

Sementara itu, tindakan pelanggaran oleh agen bukan negara(nonnegara) dalam wilayah hak hak ekonomi, sosial dan budaya antara lain;a) merancang tingkat upah yang lebih rendah daripada yang dinyatakan di dalam perundang-undangan; b) kebijakan yang bersifat diskriminatif di dalam pengangkatan buruh atau pekerja atau karyawan; c) pembuangan zat pencemar. Meskipun terdapat perbedaan dari sisi pelaku antara pemerintah dan nonpemerintah, sebagian besar para ahli berpendapat bahwa pelanggaran hak asasi harus dilekatkan hanya pada pemerintah karena tindakan tindakan pelaku bukan pemerintah dilihat sebagai tanggung jawab negara yang dianggap gagal mencegah atau melawan tindakan tindakan itu.

Sebagaimana konsep pelanggaran HAM, pada konsepsi pelanggaran HAM yang berat juga tidak terdapat satu pemahaman yang disepakati secara umum dan menjadi standar untuk dipergunakan setiap kali menyebut istilah "pelanggaran HAM yang berat". Menurut pendapat Suparman Marzuki, istilah "pelanggaran HAM berat" biasanya ditujukan terhadap kejahatan genosida, kejahatan perang, dan kejahatan terhadap kemanusiaan (Eddy, O.S., Hiariej, 2010). Ketiga jenis kejahatan inilah yang merupakan Pelanggaran HAM yang berat, dan dapat dikualifikasikan sebagai "delicta jure gentium" (Istilah Delicta Jure Gentium digunakan untuk menggantikan istilah ' Hostis Humanis Generis' yang berasal dari istilah lain yang lebih tua yaitu ' Commune hostis hone ' atau 'musuh umat manusia'. Istilah tersebut pertama kali disampaikan oleh Cicero yang tercermin dalam hukum Romawi abad ke-16. Istilahistilah tersebut diberikan kepada pelaku kejahatan Internasional). Kejahatankejahatan yang demikian juga merupakan pengingkaran terhadap "jus cogens" Uus Cogens adalah hukum pemaksa yang harus ditaati oleh bangsa-bangsa beradab di dunia sebagai prinsip dasar yang umum 
Aulia Rosa Nasution, Penyelesaian Kasus Pelanggaran HAM Berat melalui Pengadilan Nasional dan Internasional serta Komisi Kebenaran dan Rekonsiliasi

dalam hukum Internasional yang berkaitan dengan moral).

Dalam istilah asing terdapat beberapa istilah yang menggambarkan pelanggaran HAM berat yaitu " gross and systematic violations", "the most serious crimes", "gross violations", "grave violations", "grave violations", atau lebih sering dikenal dengan sebutan "gross violation of human rights". H.Victor conde merumuskan pelanggaran HAM berat sebagai (H. Victor Conde, 1999):

A term uses but not well defined in human rights resolutions, declarations, and treaties but generaly meaning systematic violations of certain human rights norms of a more serious nature , such as apartheid, racial discrimination, murder, slavery, genocide, religious persecution an a massive scale committed as a matter of official practice. Gross Violation result in irreparable harm to victims.

Sementara itu terdapat pandangan bahwa apa yang dianggap sebagai pelanggaran HAM yang berat adalah sesuatu yang langsung mengancam kehidupan atau integritas fisik seseorang. Penggunaan kata "berat" disini mengacu pada tiga hal yang bersifat kumulatif yaitu ; (a) menunjuk pada seriusnya perbuatan atau tindakan, baik dalam arti jenis perbuatan, cara maupun metode tindakan; (b) akibat yang ditimbulkan ;(c) pada jumlah korban. Kualifikasi lainnya untuk menyatakan suatu pelanggaran HAM masuk kategori berat atau bukan didasarkan juga pada sifat kejahatan, yaitu sistematis (systematic) dan meluas (widespread). Sistematis dikonstruksikan sebagai suatu kebijakan atau rangkaian tindakan yang telah direncanakan.
Sementara itu meluas menunjuk pada akibat tindakan yang menimbulkan banyak korba dan kerusakan yang parah secara luas.

Di dalam hukum nasional Indonesia, Pelanggaran HAM Berat diatur dalam UU No. 26 tahun 2000 tentang Pengadilan HAM tetapi tidak memuat definisi pelanggaran HAM berat hanya menjelaskan bahwa pelanggaran HAM berat adalah pelanggaran HAM sebagaimana dimaksud dalam undangundang (Pasal 1 angka 2 UU No. 26 tahun 2006 tentang Pengadilan HAM). Sementara itu di dalam Pasal 7 hanya memuat kejahatan yang termasuk "pelanggaran HAM yang berat" yaitu kejahatan genosida (Adapun yang dimaksud dengan genosida didefinisikan oleh Konvensi tentang Pencegahan dan Penghukuman Kejahatan Genosida tahun 1948 Pasal II yaitu : "Setiap tindakan yang dilakukan dengan maksud untuk menghancurlam, seluruh atau sebagian, kelompok kebangsaan, etnis, rasial atau keagamaan". Tindakan tersebut adalah ; (a) membunuh anggota kelompok: (b) menyebabkan bahaya badan atau mental yang serius pada anggota kelompok; (c) secara sengaja menciptakan kehidupan kelompok yang diperhitungkan akan mengakibatkan kehancuran fisik seluruh atau sebagian kelompok tersebut; (d) memaksakan tindakan dengan maksud mencegah kelahiran dalam kelompok tersebut di atas: dan (e) me Konvensi tentang Pencegahan dan Penghukuman Kejahatan Genosida, http://referensi.elsam.or.id/wpcontent/uploads/2014/10/konvensikejahatan-genosida.pdf , diakses pada tanggal 13 Desember 2016 memindahkan 
secara paksa anak- anak dari kelompok tersebut di atas ke suatu kelompok lain) dan kejahatan terhadap kemanusiaan (Pasal 7 UU No. 26 tahun 2000 tentang Pengadilan HAM).

Menurut Pasal 8 UU No. 26 Tahun 2000 tentang pengadilan HAM yang dimaksud dengan, kejahatan genosida adalah setiap perbuatan yang dilakukan dengan maksud untuk menghancurkan atau memusnahkan seluruh atau sebagian kelompok bangsa, ras, kelompok etnis, kelompok agama dengan cara: (a) membunuh anggota kelompok, (b) mengakibatkan penderitaan fisik atau mental yang berat terhadap anggotaanggota kelompok; (c) menciptakan kondisi kehidupan kelompok yang akan mengakibatkan kemusnahan secara fisik seluruh atau sebagiannya; (d) memaksakan tindakan-tindakan yang bertujuan mencegah kelahiran di dalam kelompok ; atau (e) memindahkan secara paksa anak- anak dan kelompok tertentu ke kelompok lain.

Selanjutnya, di dalam UU No. 26 tahun 2000 tentang Pengadilan HAM menyebutkan bahwa kejahatan terhadap kemansiaan adalah salah satu perbuatan yang dilakukan sebagai bagian dari serangan yang meluas atau sistematik yang diketahuinya bahwa serangan tersebut ditujukan secara langsung terhadap penduduk sipil berupa: (a) pembunuhan; (b) pemusnahan; (c) perbudakan; (d) pengusiran atau pemindahan penduduk; (e) perampasan kemerdekaan atau perampasan kebebasan fisik lain secara sewenangwenang yang melanggar (asas-asas) ketentuan pokok hukum internasional; (f) penyiksaan; (g) perkosaan, perbudakan seksual, pelacuran secara paksa, pemaksaan kehamilan, pemandulan atau sterilisasi secara paksa, atau bentuk bentuk kekerasan seksual lainnya yang setara; (h) penganiayaan terhadap suatu kelompok tertentu atau perkumpulan yang didasari persamaan paham politik, ras, kebangsaan, etnis, budaya, agama jenis kelamin, atau alasan lain yang telah diakui secara universal sebagai hal yang dilarang menurut hukum internasional; (i) penghilangan orang secara paksa; (j) kejahatan Apartheid.

Dari dua jenis pelanggaran HAM yang berat yaitu genosida dan kejahatan terhadap kemanusiaan yang diatur dalam UU No. 26 Tahun 2000 tentang Pengadilan HAM , sejauh ini belum ada contoh peristiwa praktik pelanggaran genosida seperti yang diatur dalam Statuta Roma 1998. Pengadilan HAM yang telah digelar di Indonesia melalui Pengadilan HAM ad hocseluruhnya adalah kejahatan terhadap kemanusiaan; dua diantaranya pelanggaran HAM masa lalu yaitu kasus Timor Timur dan Tanjung Priok, serta kasus peradilan HAM permanen yaitu Abepura.

\section{Penyelesaian Pelanggaran HAM Berat melalui Pengadilan HAM}

Pembentukan Mahkamah Pidana Internasional tidak dapat dilepaskan dengan masih banyaknya pelanggaran berat hak asasi manusia yang terjadi di berbagai kawasan dunia. Selama itu, penanganan pelanggaran berat HAM baik terkait lembaganya maupun pada penghukumannya belum ada kesepakatan secara internasional. Pelanggaran berat HAM (Gross Violation of Human Rights) sering terjadi di negara-negara otoritarian. 
Aulia Rosa Nasution, Penyelesaian Kasus Pelanggaran HAM Berat melalui Pengadilan Nasional dan Internasional serta Komisi Kebenaran dan Rekonsiliasi

Ketika proses demokrasi bergulir pada suatu negara, maka timbul masalah pertanggungjawaban hukum atas terjadinya pelanggaran tersebut (Mahsyur Effendi, 2004).

Pelbagai upaya nasional maupun internasional yang dilakukan banyak negara untuk meminta pertanggungjawaban atas pelanggaran HAM yang dilakukan rezim otoritiran di sejumlah negara di dunia ini dimaksudkan untuk mengakhiri atau memutus rantai impunitas (impunity) (Suparman Marzuki diambil dalam Mahrus Ali \& Syarif Nurhidayat, 2011). Politik hukum penyelesaian pelanggaran HAM berat di masa lalu melalui pengadilan ditujukan untuk mengakhiri atau memutus rantai "impunity" yaitu suatu tindakan kekuasaan yang tidak mengambil tindakan hukum apapun atas suatu kejahatan yang dilakukan atau dengan kata lain meminta pertanggungjawaban pelaku atas perbuatan yang belum dipertanggungjawabkan (Suparman Marzuki). Tidak dipenuhinya kewajiban negara untuk menuntut, mengadili dan menghukum pelaku telah menimbulkan impunitas bagi pelaku pelanggaran HAM berat.

Praktik impunitas telah terjadi sejak berabad lamanya di pelbagai negara dan terus berlangsung hingga sekarang ini. Eropa pernah gagal membentuk pengadilan Internasional terhadap Raja Wilhelm II atas kejahatannya yang melawan moralitas internasional sebagaimana yang telah direkomendasikan oleh Perjanjian Versailles. Impunitas juga dinikmati pula oleh Kaisar Hirohito oleh Mahkamah Tokyo atas keputusan AS, dan membiarkan penjahat Perang Dunia II menjadi Kepala Megara Kerajaan Jepang, dan bahkan dia dianggap sebagai pahlawan patriotik dimana abunya ditempatkan pada Kuil Suci Sito di Yasukuni. Di Argentina, para pejabat militer tingkat menengah dari pemerintahan junta yang mengibarkan perang kotor untuk menentang orang orang yang melawan mereka, melakukan penyiksaan dan melenyapkannya dengan cara membuang mereka dari pesawat terbang di atas Lautan Atlantik, sementara itu para Jenderal tersebut mendapat pengampunan.

Fenomena impunitas di Indonesia juga terjadi di era Orde Baru yang banyak sekali melakukan pelanggaran HAM berat namun tidak satu pun pelaku pelanggaran HAM berat di era terebut dapat dimintai pertanggungjawaban dalam bentuk apapun. Dari beberapa kasus impunitas tersebut menunjukkan bahwa setiap negara termasuk negara luar bahkan PBB sekalipun berpeluang untuk melindungi pelaku kejahatan HAM berat sebagai akibat adanya kepentingan politik, ideologis, dan ekonomi dibandingkan penegakan HAM dan keadilan.

Gerakan untuk melawan impunitas secara efektif dengan cepat mendapat dukungan yang sangat luas sebagaimana tercermin dalam Konferensi HAM Dunia di Wina 1993. Dalam paragraph 60 Deklarasi Wina disebutkan bahwa pengadilan atas pelanggaran HAM akan memberi basis hukum yang kuat bagi tegaknya supremasi hukum yang berkeadilan (the rule of law). 
Mekanisme Penyelesaian Kasus - kasus Pelanggaran HAM Berat melalui Pengadilan Nasional

Hukum Internasional mengenal prinsip "exhaustion of domestic remedies" yang mengharuskan penggunaan semaksimal mungkin semua upaya hukum yang terseda di tingkat nasional terlebh dahulu sebelum menggnakan mekanisme remedi di tingkat internasional dan regional. Dengan kata lain,mekanisme remedi internasional hanya diperlukan bila mekanisme remedi nasional tidak bekerja secara efektif sehingga korban merasa belum mendapatkan keadilan. Beberapa contoh penggunaan mekanisme nasional, seperti terbentuknya pengadilan HAM nasional di Sierra Lene sebagai "Internationalize domestic tribunal"dengan nama "Special Court"; di Kamboja dibentuk dengan nama "Extraordinary chambers" dan di Timor Leste disebut "Special Panels" untuk mengadili para pelaku kejahatan internasional tertentu seperti genosida, kejahatan perang, dan penyiksaan.

Selain itu

penyelesaian pelanggaran HAM yang berat di tingkat nasional juga dapat dilakukan melalui pengadilan nasional atas dasar prinsip yurisdiksi universal. Berdasarkan prinsip tersebut, setiap negara memiliki kompetensi untuk melaksanakan yurisdiksinya dalam mengadili para pelaku kejahatan internasional tertentu seperti genosida, kejahatan perang dan penyiksaan. Adapun dasar penggunaan yurisdiksi universal adalah bahwa kejahatan-kejahatan tersbut dianggap menyangkut umat manusia secara keseluruhan (Suparman Marzuki). Penggunaan yurisdiksi universal ditujukan untuk mencegah adanya tempat berlindung bagi para pelaku pelanggaran HAM berat .

Dengan sistem ini maka terhadap pelaku yang berada di wilayah yurisdiksi suatu negara, negara tersebut harus mengadili dan menghukum pelaku berdasarkan hukum pidananya atau mengekstradisikan ke negara lain yang memiliki dan henda melaksanakan yurisdiksinya. Salah satu contoh penggunaan prinsip jurisdiksi universal adalah kasus Pinochet mantan diktator Cile yang melakukan pelanggaran HAM berat ketika berkuasa di Cile untuk ditangkap dan diekstradisi ke Spanyol atas dakwaaan melakukan tindakan penyiksaan, pembunuhan dan penculikan (Suparman Marzuki). Penerapan yurisdiksi universal juga dapat dilihat di Israel dalam kasus Adolf Eichmann, seorang warga negara Jerman yang melaksanakan eksekusi bagi sekitar 5 juta jiwa orang Yahudi di Eropa, yang akhirnya dijatuhi hukuman mati karena terbukti melakukan kejahatan terhadap kemanusiaan, kejahatan perang, dan kejahatan genosida terhadap bangsa Yahudi.

Upaya peradilan terhadap para pelaku pelanggaran HAM berat menjadi tanggung jawab negara dan bangsa Indonesia serta masyarakat Internasional secara keseluruhan. Ini artinya bahwa yurisdiksi pengadilan internasional tetap masih terbuka bagi suatu negara meskipun negara tersebut termasuk Indonesia secara khusus sudah memiliki pengadilan HAM.

Menurut Pasal 1 angka 3 menentukan bahwa yang dimasud dengan Pengadilan Hak Asasi Manusia atau 
Aulia Rosa Nasution, Penyelesaian Kasus Pelanggaran HAM Berat melalui Pengadilan Nasional dan Internasional serta Komisi Kebenaran dan Rekonsiliasi

Pengadilan HAM adalah pengadilan khusus terhadap pelangaran HAM yang berat. Dengan demikian Pengadilan HAM adalah pengadilan yang berada di lingkungan peradilan umum yang hanya bertugas dan berwenang untuk memeriksa dan memutus perkara pelanggaran berat HAM. Pelanggaran berat HAM merupakan "extra ordinary crimes"dan berdampak secara luas baik pada tingkat nasional maupun internasional dan bukan merupakan tindak pidana yang diatur dalam KUHP serta menimbulkan kerugian baik materiil maupun immaterial yang mengakibatkan perasaan tidak aman, baik terhadap perseorangan maupun masyarakat, sehingga perlu dipulihkan dalam mewujudkan supremasi hukum dan perlindungan hak-hak asasi manusia di Indonesia (Syawal Abdulajid \& Anshar, 2010).

Pengadilan HAM mempunyai tugas dan wewenang untuk memeriksa dan memutus perkara pelanggaran berat HAM. Pelanggaran HAM berat yang dimaksud adalah perkara pelanggaran berat HAM yang terjadi sesudah berlakunya UU No. 26 Tahun 2000 tentang Pengadilan HAM.

Menurut Pasal 2 Undang-Undang ini dinyatakan bahwa Pengadilan HAM merupakan pengadilan khusus yang berada di lingkungan Peradilan Umum. Yang dimaksud dengan Pasal 2 mengenai kalimat " di lingkungan Peradilan Umum" adalah bahwasanya Pengadilan HAM berada di dalam lingkungan Peradilan Umum seperti yang dimaksud oleh Pasal 10 Ayat 1 huruf a UU No. 14 Tahun 1970 tentang Kekuasaan Kehakiman yang menentukan bahwa kekuasaan kehakiman dilakukan oleh pengadilan dalam lingkungan ; a) Peradilan Umum; b) Peradilan Agama; c) Peradilan Militer; c) Peradilan Tata Usaha Negara (Pasal 10 Ayat 1 UU No. 14 Tahun 1970 tentang Kekuasaan Kehakiman). Dengan demikian apa yang dimaksud dengan Pengadilan HAM adalah pengadilan yang merupakan pengkhususan (diferensiasi/spesialisasi) dari pengadilan di lingkungan Peradilan Umum yang tugas dan wewenangnya hanya memeriksa dan memutus perkara pelanggran HAM yang berat saja ( $R$. Wiyono, 2006).

Pasal 4 menentukan bahwa Pengadilan bertugas dan berwenang memeriksa dan memutus perkara pelanggaran HAM yang berat. Dengan demikian yang dimaksud dengan Pengadilan HAM disini adalah pengadilan yang berada di lingkungan Peradilan Umum yang hanya bertugas dan berwenang untuk memeriksa dan memutus perkara pelanggaran HAM yang berat saja (R. Wiyono, 2006). Karena kekuasaan kehakiman di lingkungan Peradilan Umum dilaksanakan oleh Pengadilan Negeri sebagai Pengadilan Tingkat Pertama yang berkedudukan di Ibu Kota daerah kota atau daerah kabupaten dan Pengadilan Tinggi sebagai Pengadilan Tingkat Banding yang berkedudukan di ibu kota provinsi, padahal Pasal 3 Ayat (1) menentukan bahwa Pengadilan HAM berkedudukan di daerah kota atau daerah kabupaten maka hanya dapat diketahui bahwa pengkhususan (diferensiasi/spesialisasi) hanya ada di Pengadilan Negeri saja artinya pembentukan Pengadilan HAM hanya ada pada Pengadilan Negeri saja. 
Sayangnya di dalam UU No. 26 Tahun 2000 tidak terdapat ketentuan tentang cara pembentukan Pengadilan HAM, yang ada hanya cara pembentukan Pengadilan HAM ad hoc yaitu dengan Keputusan Presiden seperti yang ditentukan dalam Pasal 43 Ayat (2) UU No. 26 Tahun 2006 tentang Pengadilan HAM. Di dalam praktik menunjukkan bahwa cara pembentukan Pengadilan HAM juga dilakukan dengan Keputusan Presiden, misalnya Keputusan Presiden Nomor 31 Tahun 2001 tentang Pembentukan Pengadilan HAM pada Pengadilan Negeri Jakarta Pusat, Pengadilan Negeri Surabaya , Pengadilan Negeri Medan, dan Pengadilan Makassar sebagai pelaksanaan dari Pasal 45.

Adapun alasan mengapa pemerintah perlu utuk memeriksa dan memutus perkara pelanggaran HAM berat di pengadilan HAM , telah dituangkan di dalam Penjelasan Umum UU Pengadilan HAM atas dasar pertimbangan sebagai berikut; 1) pelanggaran HAM yang berat yang merupakan "extra ordinary crimes" dan berdampak secara luas, baik pada tingkat nasional maupun internasional dan bukan merupakan tindak pidana yang diatur dalam KUHP serta menimbulkan kerugan, baik materiil maupun immaterial yang mengakibatkan perasaaan tidak aman, baik terhadap perseorangan maupun masyarakat, sehingga perlu segera dipulihkan dalam mewujudkan supremasi hukum untuk mencapai kedamaian, ketertiban, ketentraman, keadilan, dan kesejahteraan bagi seluruh masyarakat Indonesia; 2) terhadap perkara pelanggaran HAM yang berat diperlukan langkah-langkah penyidikan, penuntutan dan pemeriksaan yang bersifat khusus yaitu: a) diperlukan penyelidikan dengan membentuk tim ad hoc, penyidik ad hoc, penuntut umum ad hoc dan hakim ad hoc; b) diperlukan penegasan bahwa penyelidikan, hanya dilakukan oleh Komnas HAM, sedangkan penyidik tidak berwenang menerima laporan atau pengaduan sebagaimana diatur dalam KUHAP; c) diperlukan ketentuan mengenai tenggang waktu tertentu untuk melakukan penyidikan, penuntutan, dan pemeriksaaan di pengadilan; d) diperlukan ketentuan menenai perlindungan korban dan saksi; e) diperlukan ketentuan yang menegaskan tidak ada kadaluwarsa bagi pelanggaran HAM yang berat.

Mengenai lingkup kewenangan absolut atau kompetensi absolut dari Pengadilan HAM oleh Pasal 4 ditentukan bahwa Pengadilan HAM mempunyai tugas dan wewenang untuk memeriksa dan memutus perkara pelanggaran HAM yang berat dan sudah tentu yang dimaksud dengan perkara pelanggaran HAM ini adalah perkara pelanggaran HAM yang berat yang terjadi sesudah berlakunya UU No. 26 Tahun 2000 tanggal 23 November 2000.

Di dalam Pasal 1 angka 2 ditentukan bahwa yang dimaksud dengan pelanggaran HAM yang berat adalah HAM sebagaimana yang dimaksud dalam UU No. 26 Tahun 2000 artinya seperti yang ditentukan oleh Pasal 7 yaitu pelanggaran HAM yang berat meliputi; a) kejahatan genosida; b) kejahatan terhadap kemanusiaan. Sehingga yurisdiksi hukum yang dapat diterima dan diterapkan oleh Pengadilan HAM adalah hanya memeriksa, mengadili , dan memutuskan 
Aulia Rosa Nasution, Penyelesaian Kasus Pelanggaran HAM Berat melalui Pengadilan Nasional dan Internasional serta Komisi Kebenaran dan Rekonsiliasi

kasus-kasus kejahatan genosida dan kejahatan terhadap kemanusiaan. Pertimbangan mengapa pembuat undang-undang hanya memasukkan genosida dan kejahatan terhadap kemanusiaan yang menjadi yurisdiksi Pengadilan HAM adalah disebabkan menurut pertimbangan dari sisi hukum dan politis bahwa dua jenis kejahatan ini sangat berarti dan menentukan bagi peradaban bangsa Indonesia sejak kini dan di masa yang akan dating (Romli Atmasasmita, 2004).

$$
\text { Di dalam Pasal } 3 \text { Ayat (1) }
$$
menentukan tempat kedudukan dari Pengadilan HAM yaitu daerah hukum Pengadilan HAM meliputi darerah huukum Pengadilan Negeri yang bersangkutan. Mengenai kedudukan Pengadilan HAM dijelaskan dalam Pasal 45 Ayat (1) jo . Ayat (2) ditentukan pada saat mulai berlakunya UU No. 26 Tahun 2000 pada tanggal 25 November 2000 dibentuk Pengadilan HAM sebagia berikut;

a) Pengadilan HAM pada Pengadilan Negeri Jakarta Pusat dengan daerah huku yang meliputi wilayah; a.1. Daerah Khusus Ibukota Jakarta; a. 2. Provinsi: Jawa Barat, Banten, Sumatera Selatan, Lampung, Bengkulu, Kalimantan Barat, dan Kalimantan Tengah.

b) Pengadilan HAM pada Pengadilan Negeri Surabaya dengan daerah hukum yang meliputi provinsi: Jawa Timur, Jawa Tengah, Bali, Kalimantan Selatan, Kalimantan Timur, Nusa Tenggara Barat, Nusa Tenggara Timur dan Daerah Istimewa Yogjakarta

c) Pengadilan HAM pada Pengadilan Negeri Makassar dengan daerah huku yang meliputi wilayah provinsi; Sulawesi Selatan, Sulawesi Tenggara, Sulawesi Tengah, Maluku, Maluku Utara dan Irian Jaya

d) Pengadilan HAM pada Pengadilan Negeri Medan dengan daerah hukum yang meliputi wilayah provinsi; Sumatera Utara, Riau, Jami, Sumatera Barat, dan Daerah Istimewa Aceh.

Karena kejahatan genosida dan kejahatan terhadap kemanusiaan adalah termasuk yurisdiksi Mahkamah Pidana Internasional (ICC) dan juga termasuk yurisdiksi Pengadilan HAM, maka hubungan antara keduanya dapat dijelaskan bahwa yurisdiksi dari Mahkamah Kejahatan Internasional adalah merupakan pelengkap terhadap yurisdiksi dari Pengadilan Kejahatan Internasional. Maksudnya, yurisdiksi dari Mahkamah Kejahatan Internasional baru dapat dilaksanakan jika proses peradilan yang efektif melalui tindakan hukum di tingkat nasional tidak dapat dilaksanakan (R. Wiyono, 2006). Dengan demikian Mahkamah Pidana Internasional tidak mempunyai yurisdiksi secara langsung atau serta merta terhadap pelangggaran Hak Asasi Manusia yang berat yang terjadi.

Sebagai penjabaran lebih lanjut dari ketentuan bahwa Mahkamah Pidana Internasional adalah merupakan pelengkap terhadap yurisdiksi hukum pidana nasional, Pasal 17 ayat (1) Statuta Roma menentukan bahwa suatu kasus tidak dapat diterima oleh Mahkamah Pidana Internasional jika:

a. Kasusnya sedang diadakan penyidikan atau penuntutan oleh suatu negara yang mempunyai 
yurisdiksi atas kasus tersebut kecuali kalau negara tersebut tidak bersedia atau benar-benar tidak mampu melakukan penyidikan atau penuntutan;

b. Kasusnya telah diadakan penyidikan oleh suatu negara yang mempunyai yurisdiksi atas kasus tersebut dan negara itu telah memutuskan untuk tidak mengadakan penuntutan orang yag bersangkutan, kecuali kalau keputusan itu timbul dari ketidaksediaan atau ketidakmampuan negara tersebut untuk benar-benar melalukan penuntutan

c. Orang yang bersangkutan telah diadili untuk perbuatan yang menjadi dasar dakwaan dan dalam suatu sidang oleh Mahkamah PIdana Internasional telah diputuskan tidak dapat diadili berdasarkan Pasal 20 Ayat (3)

d. Kasusnya tidak cukup berat untuk membenarkan tindakan lebih lanjut

Disamping Pasal 17 Ayat (1) Statuta Roma, yang termasuk penjabaran lebih lanjut dari ketentuan bahwa Mahkamah Pidana Internasional adalah merupakan pelengkap terhadap yurisdiksi hukum nasional .

Mekanisme Penyelesaian Kasus-kasus Pelanggaran HAM Berat Melalui Pengadilan Internasional

Kepedulian internasional terhadap hak asasi manusia merupakan gejala yang relatif baru. Menurut pendapat Scott Davidson, terdapat kaitan yang sangat erat antara perlindungan terhadap hak asasi manusia di tingkat nasional dan di tingkat internasional. Semua instrumen internasional mewajibkan sistem konstitusional domestik setiap negara memberikan kompensasi yang memadai kepada orang-orang yang haknya dilanggar. Mekanisme internasional untuk menjamin Hak Asasi Manusia baru akan melakukan perannya apabila sistem perlindungan di dalam negara itu sendiri goyah atau bahkan tidak ada. Dengan demikian, mekanisme internasional sedikit banyak berfungsimemperkuat perlindungan domestik terhadap hak asasi manusia dan menyediakan pengganti jika sistem domestik gagal atau tidak memadai (Scott Davidson, 2008).

Upaya peradilan terhadap pelaku pelanggaran berat melalui mekanisme pengadilan Internasional pernah dilakukan saat dibentuknya dua pengadilan internasional yang bersifat ad hoc yaitu a) International Military Tribunal-IMT Nuremberg di Jerman dan b) International Military Tribunal for the Far Eastdi Tokyo , yang lebih dikenal dengan Tokyo Tribunal, dimana keduanya dibentuk saat itu untuk mengadili para penjahat perang yang melakukan pelanggaran HAM berat pasca Perang Dunia II. Sejak berakhirnya peradilan Nuremberg, Jerman dan Tokyo, Jepang pada tahun 1948, pengadilan Internasional yang dibentuk untuk menyelesaikan pelanggaran HAM yang berat tidak pernah dibentuk lagi. Hal itu bukan karena tidak pernah terjadi lagi kejahatan serius, tetapi karena pada masa perang dingin sampai akhir tahun 1980an , kekuatan blok Barat dan blok Timur saling mencegah terbentuknya pengadilan internasional untuk mengadili kejahatan yang dilakukan oleh salah satu anggota blok tersebut (Suparman Marzuki, 2010).

Baru setelah Perang Dingin usai, dibentuklah dua pengadilan Internasional 
ad hoc yaitu a) International Criminal Tribunal for Yugoslavia-ICTY dan b) International Criminal Tribunal for Rwanda-ICTY untuk mengadili para pelaku pelanggaran HAM berat selama kurang lebih 50 tahun setelah dibentuknya International Military of Nuremberg dan Tokyo Tribunal. Dua pengadilan internasional tersebut (Yugoslavia dan Rwanda) merupakan katalisator penting terbentuknya suatu pengadilan yang permanen yaitu Mahkamah Pidana Internasional (ICC).

ICC dibentuk berdasarkan Statuta Roma (Rome Statute of International Criminal Court 1998) (Statuta Roma 1998 adalah suatu perjanjian internasional yang hanya mengikat negara-negara yang mengekspresikan secara formal keinginan masing-masing negara untuk terikat pada isi perjanjian tersebut. Negara-negara tersebut kemudian menjadi "State Parties" (negara pihak) dari statute tersebut jika telah meratifikasinyam namun ada juga sejumlah negara yang baru menandatangani konvensi tersebut tetapi belum meratifikasinya sebagai bagian dari undang-undang nasionalnya termasuk Indonesia. Sejak Statuta Roma dibentuk dan diberlakukan pada 1 Juli 2002, tercatat 122 negara telah menjadi negara pihak dari perjanjian dan 31 negara telah menandatangani statuta tersebut) dan merupakan suatu lembaga permanen yang dibentuk untuk mengadili pelanggaran HAM berat. ICC merupakan lembaga hukum independen dan permanen yang dibentuk oleh masyarakat negara-negara internasional untuk menjatuhkan hukuman kepada setiap bentuk kejahatan menurut hukum internasional yang dicakup dalam Statuta ini yaitu; a) genosida, b) kejahatan terhadap kemanusiaan, c) kejahatan perang; d) agresi. Meskipun lebih dari setengah abad yang lalu komunitas internasional telah menetapkan sistem regional dan internasional untuk memberikan perlindungan terhadap hak-hak asasi manusia, jutaan manusia masih menjadi korban genosida,kejahatan terhadap kemanusiaan dan kejahatan perang. Namun hanya sedikit pelaku kejahatan hak asasi manusia yang diadili oleh Pengadilan Nasional.

Adapun tujuan dibentuknya ICC antara lain; a) mengakhiri impunitas; b) membantu mengakhiri konflik; c) memperbaiki kelemahan proses pengadilan ad-hoc; d) mengambil alih pada saat institusi pengadilan pidana nasional tidak mau atau tidak mampu untuk mengadili kejahatan serius di negaranya; e) mengusahakan agar para korban dan keluarganya dapat memiliki kesempatan untuk mendapatkan keadilan dan kebenaran, dan memulai proses rekonsiliasi; f) mencegah orang atau pihak-pihak yang berencana melakukan kejahatan serius menurut hukum internasional (Iman Santosa, 2013).

Yurisdiksi mahkamah ini meliputi kejahatan yang terjadi setelah tanggal 11 Juli 2002 antara lain; (1) kejahatan Genosida (the crime of genocide); (2) Kejahatan terhadap kemanusiaan (Crimes against humanity); (3) Kejahatan Perang (War Crimes); (4) kejahatan Agresi (The Crime of Aggression). Selain itu mahkamah juga memiliki yurisdiksi yang bersifat komplementer atas pengadilan nasional yang menegaskan bahwa ICC adalah pelengkap (komplementer) bagi 
pengadilan nasional. ICC baru hanya dapat digunakan apabila pengadilan nasional tidak mampu (unable) atau tidak mau (unwilling) mengadili kejahatan HAM yang serius.

ICC juga dilarang melaksanakan peradilan terhadap kejahatan yang sama yang sedang diselidiki atau dituntut dalam pengadilan nasional suatu negara termasuk juga apabila kasusnya telah diselidiki oleh suatu negara yang mempunyai yurisdiksi atas kasus tersebut, dan negara itu telah memutuskan untuk tidak menuntut orang yang bersangkutan kecuali jika keputusan tersebut timbul dari ketidaksediaan atau ketidakmampuan negara tersebut untuk benar-benar melakukan penuntutan; atau kasusnya tidak cukup gawat untuk membenarkan tindakan lebih lanjut oleh ICC (Pasal 17 Statuta Roma 1998). Dengan demikian, ICC merupakan the last resort (ultimum remedium) sebagai pelengkap dan jaminan penghormatan penggunaan mekanisme hukum (pengadilan) nasional. Berbeda dengan pengadilan Internasional ad hoc sebelumnya, ICC merupakan pengadilan permanen, independen, bukan organ PBB karena dibentuk berdasarkan perjanjian multilateral antara negara-negara di dunia. Akan tetapi antara pengadilan dan PBB memiliki hubungan formal dimana Dewan Keamanan PBB memiliki peranan yang signifikan di dalam pelaksanaan yurisdiksi pengadilan yaitu DK PBB memiliki wewenang untuk memulai atau menunda dilakukannya investigasi terhadap pelaku kejahatan berdasarkan bab VII Piagam PBB.

Adapun yang menjadi yurisdiksi ICC meliputi; (1) Territorial Jurisdiction (rationae loci); yurisdiksi ICC hanya berlaku dalam wilayah negara pihak, yurisdiksi juga diperluas bagi kapal atau pesawat terbang yang terdaftar di negara pihak dan dalam wilayah bukan negara pihak yang mengakui yurisdiksi IC berdasarkan deklarasi ad hoc (Pasal 12 Statuta Roma 1998); (2) Material Jurisdiction (rationae materiae); kejahatan yang menjadi yurisdiksi ICC terdiri dari kejahatan terhadap kemanusiaan , kejahatan perang , genosida dan kejahatan agresi (Pasal 5-8 Statuta Roma 1998); (3) Temporal Jurisdiction (rationae temporis). ICC baru bisa memiliki yurisdiksi terhadap kejahatan yang diatur dalam Statuta setelah Statuta Roma berlaku yaitu 1 Juli 2002 (Pasal 11 Statuta Roma 1998); (4) Personal Jurisdiction (rationae personae); ICC memiliki yurisdiksi atas orang (natural person) di mana pelaku kejahatan dalam yurisdiksi ICC harus mempertanggungjawabkan perbuatannya secara individu (individual criminal responsibility) , termasuk pejabat pemerintahan, komandan baik militer maupun sipil (Pasal 17 ayat 2 butir a Statuta Roma 1998).

ICC juga menggunakan prinsip "trigger mechanism" di dalam penyelidikan kasus pelanggaran HAM berat. Prinsip tersebut menjelaskan beberapa hal yaitu;1) negara pihak boleh melaporkan suatu keadaan kepada penuntut umum tentang telah terjadinya atau lebih kejahatan yang merupakan yurisdiksi (Pasal 13 (a) dan Pasal 14 Statuta Roma); 2) atas inisiatif penuntut umum untuk melakukan penyelidikan proprio motu (tindakan berdasarkan inisiatif sendiri) karena adanya informasi dari sumber yang bisa dipertanggungjawabkan bahwa 
Aulia Rosa Nasution, Penyelesaian Kasus Pelanggaran HAM Berat melalui Pengadilan Nasional dan Internasional serta Komisi Kebenaran dan Rekonsiliasi

telah terjadi kejahatan yang menjadi yurisdiksi ICC; 3) Atas dasar laporan dari Dewan Keamanan PBB mengenai situasi telah terjadinya satu atau lebih kejahatan yang berada dalam yurisdiksi ICC sesuai dengan Bab VII Piagam PBB Pasal 13 (b) dan 52 (c) Statuta Roma (A Join Project of Rights and Democract and The International Center for Criminal Law Reform and Criminal Justice Policy, 2002).

Mekanisme Penyelesaikan Kasus-kasus Pelanggaran HAM Berat melalui Pengadilan Campuran (Hybridcourt)

Selain mekanisme nasional dan internasional, mekanisme lain yang merupakan mekanisme baru untuk menegakkan keadilan dalam kasus pelanggaran HAM berat adalah melalui pengadilan campuran atau "Hybrid Tribunal". Model pengadilan ini muncul sebagai kritik terhadap kelemahan pengadilan nasional dan pengadilan internasional seperti pengadilan kejahatan internasional untuk Rwanda dan Yugoslavia.

Model pengadilan campuran pertama kali dilaksanakan di TimorTimur, kemudian dilaksanakan di Kamboja serta Sierra Leone dimana model pengadilan seperti ini menggabungkan kekuatan pengadilan ad hoc internasional dengan pengadilan nasional atau domestik. Pada pengadilan ICTY dan ICTR, PBB bertanggungjawab menyediakan biaya, sumber daya, hakim dan jaksa penuntut umum. Hukum materiil yang diterapkan dalam persidangan juga tidak hanya hukum nasional negara yang bersangkutan tetapi juga menggunakan norma-norma dari berbagai instrumen hukum HAM Internasional.

Apresiasi terhadap pengadilan HAM campuran ini cukup baik karena dinilai lebih memiliki nilai legitimasi sebagai suatu mekanisme yang adil untuk mengadili para pelaku yang bertanggung jawab atas perbuatan mereka. Seperti halnya pengadilan nasional, model campuran ini lebih murah biayanya untuk dijalankan dibandingkan dengan persidangan ad hoc. Selain itu mekanisme ini dianggap lebih sedikit menimbulkan pertentangan secara politis, lebih berarti bagi komunitas korban dan lebih efektif dalam membangun kembali sistem peradilan lokal. Meskipun demikian, pengadilan campuran ini tetap mengundang kekhawatiran berupa kemungkinan mekanisme ini bukannya mengambil sisi terbaik dari sistem yuridis nasional ataupun internasional tetapi malah mengadopsi sisi buruknya, seperti yang tercermin pada pengadilan campuran Timor Timur yang faktanya menunjukkan ketidakefisienan karena meminimalkan keterlibatan lokal serta kegagalannya menjalankan standar proses yuridis yang benar (Suparman Marzuki, 2010).

Sekalipun mekanisme pengadilan campuran yang diterapkan untuk pertama kalinya di Timor Timur atau yang sekarang disebut Timor Leste memiliki kelemahan-kelemahan, tetapi mulai diyakini oleh banyak kalangan terutama PBB yang melihat mekanisme campuran ini lebih baik dibandingkan dengan mekanisme ad hoc karena dengan mekanisme ini, maka masyarakat internasional melalui PBB bisa secara langsung terlibat dan menjadi bagian 
dari proses yudisial sehingga kelemahankelemahan mekanisme nasional (domestic) berupa kerentanan politik atau kelemahan hukum dapat dieliminasi.

Mekanisme Penyelesaian Kasus-kasus Pelanggaran HAM Berat melalui Komisi Kebenaran dan Rekonsiliasi (KKR)

Komisi Kebenaran dan Rekonsiliasi adalah sebuah komisi yang ditugaskan untuk menemukan dan mengungkapkan pelanggaran-pelanggaran yang dilakukan pada masa lampau oleh suatu pemerintahan, dengan harapan menyelesaikan konflik yang tertinggal dari masa lalu. Dengan berbagai nama, komisi ini kadang-kadang dibentuk oleh negaranegara yang muncul dari masa-masa pergolakan internal, perang saudara, atau pemerintahan yang dictator (Komisi Kebenaran dan Rekonsiliasi, https://id.wikipedia.org/wiki/Komisi_Keb enaran_dan_Rekonsiliasi diakses pada 15 Desember 2016).

Sebagai contoh Komisi Kebenaran dan Rekonsiliasi di Afrika Selatan, yang dibentuk oleh PresidenNelson Mandela setelah apartheid, pada umumnya dianggap sebagai sebuah model untuk Komisi Kebenaran, yang jarang, kalaupun pernah, dicapai di tempat-tempat lain. Sebagai laporan pemerintah, mereka dapat memberikan bukti-bukti menentang revisionisme sejarah atas terorisme negara dan kejahatan-kejahatan lain serta pelanggaran-pelanggaran hak asasi manusia. Komisi-komisi kebenaran kadang-kadang dikritik karena membiarkan kejahatan tidak dihukum, dan menciptakan impunitas bagi pelanggar-pelanggar hak asasi manusia yang serius.

Komisi ini berorientasi pada penyelidikan kasus masa lampau dalam jumlah besar, dibentuk dalam waktu sementara, selama satu periode tertentu yang telah ditentukan sebelumnya, dan memperoleh beberapa jenis kewenangan sebagai upaya melukiskan seluruh pelanggaran HAM selama satu periode tertentu (Suparman Marzuki, 2010). Misi daripada komisi ini adalam melakukan rekonsiliasi (Menurut Kamus Besar Bahasa Indonesia, rekonsiliasi adalah perbuatan memulihkan hubungan persahabatan kembali pada keadaan semula atau perbuatan menyelesaikan perbedaan,

http://kbbi.web.id/rekonsiliasi diakses pada 15 Desember 2016). Misi ini didasarkan pada kepercayaan bahwa rekonsiliasi antara pelaku dan korban pelanggaran HAM membutuhkan pengungkapan kebenaran di belakang semua kejadian secara menyeluruh. Oleh karena itu, memberikan kesempatan kepada korban untuk bicara dan menerima penjelasan tentang kejadiankejadian penting yang berhubungan dnegan pelanggaran HAM di masa lalu merupakan hal yang penting. Inilah fondasi untuk mengungkap kebenaran demi menegakkan keadilan.

Rekonsiliasi dalam masyarakat pascarezim otoritarian sangat penting karena keadilan transisional lebih dari sekedar menangani pelanggaran HAM kasus per kasus tetapi juga menjadi dasar moral pemerintahan transisional dalam menghormati martabat manusia melalui cara-cara yang demokratis, non kekerasan dan sesuai dengan prinsip supremasi hukum. Semua itu bertujuan agar 
Aulia Rosa Nasution, Penyelesaian Kasus Pelanggaran HAM Berat melalui Pengadilan Nasional dan Internasional serta Komisi Kebenaran dan Rekonsiliasi

kesalahan yang sama tidak terjadi lagi di masa depan.

Komisi Kebenaran dan Rekonsiliasi (KKR) adalah fenomena yang timbul di era transisi politik dari suatu rezim otoriter ke rezim demokratis, terkait dengan persoalan penyelesaian kejahatan terhadap kemanusiaan yang dilakukan oleh rezim sebelumya. Pemerintahan transisi berusaha menjawab masalah tersebut dengan mencoba mendamaikan kecenderungan menghukum di satu sisi dengan memberi maaf atau amnesti di sisi yang lain. Sebagai "jalan tengah" tentu saja upaya demikian tidak memuaskan banyak pihak terutama korban, keluarga korban, dan organisasi masyarakat sipil tetapi cara inilah yang dapat dilakukan mengingat kejahatan terhadap kemanusiaan yang dilakukan oleh rezim sebelumnya mengandung dimensi politik, psikologis dan hukum yang sangat kompleks (Komisi Kebenaran dan Rekonsiliasi, http://pusham.uii.ac.id/ham/16_Chapter1 0.pdf hal. 413, diakses pada 15 Desember 2016).

Sejak kemunculannya pertama kali di Argentina dan Uganda pada medium 1980-an, KKR telah menjadi fenomena internasional. Lebih dari 20 negara telah memilih jalan mendirikan KKR sebagai cara mempertanggungjawabkan kejahatan hak asasi manusia yang berat yang terjadi pada masa lampau. Beberapa diantaranya berhasil meskipun sebagian juga mengalami kegagalan. Kesadaran pentingnya mengusut, mengungkap kebenaran dan meminta pertanggungjawaban rezim atas pelanggaran HAM berat di masa lalu secara teoretis diyakini banyak aktivis pro demokrasi merupakan jalan menuju demokrasi. Tidak mungkin sebuah bangsa dapat hidup bersatu padu dalam damai di atas sejarah penuh luka dan kekerasan. Proses transisi menuju demokrasi harus berjalan di atas proses sejarah yang jujur, adil dan bertanggung jawab. Pemerintahan yang baru harus menemukan jalan keluar untuk meneruskan detak nadi kehidupan, menciptakan ulang ruang nasional yang damai dan layak dihuni, membangun semangat dan upaya rekonsiliasi dengan para musuh masa lampau, dan mengurung kekejaman masa lampau dalam sangkar masa lampaunya sendiri.

KKR bukanlah lembaga yang menggantikan fungsi pengadilan karena memang bukan badan peradilan, bukan persidangan hukum dan tidak memiliki kekuasaan untuk mengirim seseorang ke penjara atau memvonis seseorang karena suatu kejahatan tertentu. Hanya saja Komisi Kebenaran dapat melakukan beberapa hal penting yang secara umum tidak dapat dicapai melalui proses penuntutan persidangan di pengadilan pidana. KKR dapat menangani kasus dalam jumlah relatiflebih besar dibandingkan dengan pengadilan pidana.

Dalam suatu situasi di mana terjadi pelanggaran HAM yang berat dan meluas dan sistematis di bawah rezim sebelumnya, Komisi Kebenaran dapat menyelidiki semua kasus atau sejumlah besar kasus yang ada secara komprehensif dan tidak dibatasi kepada penanganan sejumlah kecil kasus saja. Komisi Kebenaran berada dalam posisi untuk menyediakan bantuan praktis bagi para korban, yang secara spesifik mengidentifikasi dan membuktikan individu-individu atau keluarga-keluarga 
mana saja yang menjadi korban kejahatan masa lampau sehingga mereka secara hukum berhak untuk mendapatkan bentuk reparasi di masa yang akan dating (Suparman Marzuki, 2010). Contohnya, Komisi Rekonsiliasi dan Kebenaran di Cile yang dapat mengidentifikasi masingmasing orang dan anggota keluarga yang kemudian menjadi layak untuk berbagai fasilitas dari pemerintah di masa yang akan datang, seperti beasiswa sekolah, subsidi perumahan, asuransi kesehatan, dan pensiun.

KKR juga dapat dipakai untuk menjawab pertanyaan-pertanyaan besar seperti: bagaimana suatu pelanggaran HAM terjadi, mengapa terjadi, faktor apakah yang terdapat dalam suatu masyarakat atau dalam suatu negara yang memungkinkan kejadian tersebut terjadi, perubahan-perubahan apa saja yang harus dilakukan untuk mencegah pelanggaran HAM tidak terulang lagi di masa yang akan datang. Komisi Kebenaran juga dapat membantu terlaksananya resolusi dengan mengakui penderitaan yang dialami korban,membuat pemetaan atas pngaruh dari kejahatan di masa lalu, dan merekomendasikan reparasi. Komisi Kebenaran juga dapat merekomendasikan pembaharuan-pembaharuan tertentu didalam institusi-institusi publik, seperti di dalam kepolisian dan pengadilan dengan tujuan mencegah terulangnya kembali pelanggaran HAM.

KKRjuga dapat memilah antara pertanggungjawaban dan pengungkapan para pelaku. Komisi Kebenaran juga dapat mengurangi jumlah kebohongan yang beredar tanpa dibuktikan kebenarannya di depan public. Contoh di Argentina, pekerjaan Komisi membuat militer mustahil mengklaim bahwa mereka tidak membuang korban yang setengah mati dari helikopter ke laut, demikian halnya di Cile, di depan publikorang tidak boleh mengatakan rezim Pinochet tidak membunuh ribuan orang tidak bersalah karena Komisi Kebenaran telah mengungkapkannya (Suparman Marzuki, 2010).

Dari beberapa contoh kasus di atas dapat diketahui bahwa tugas KKR adalah mencari, menemukan dan mengemukakan fakta atau kenyataan tentang suatu peristiwa dengan segala akibatnya; menimbang dan menempatkan keadilan korban dan pelaku sebagai prinsip kerja; tidak boleh berlaku tidak fair dan tidak adil terhadap pelaku sekalipun; dan yang terakhir semua temuan harus dinyatakan secara benar, fair, jujur dan transparan, tidak manipulatif untuk mencapai tujuan rekonsiliasi yang sesungguhnya yaitu mendamaikan para pihak yang pernah bersengketa atau bermusuhan.

Rekonsiliasi sebagai kata kunci pembentukan KKR jelas terkait dengan usaha memperbaiki hubungan sosial, politik dan psikologis antara warga negara sebagai pribadi atau kelompok dengan negara akibat perlakuan atau tindakan negara yang tidak adil dan tidak manusiawi. Rekonsiliasi itu diperlukan untuk membangun masa depan bangsa dan negara yang demokratis di atas pilihan sikap memaafkan atau melupakan, dan bukan penuntutan pidana. Rekonsiliasi mensyaratkan dilakukannya pengungkapan kebenaran. Jadi yang dimaksud disini adalah rekonsiliasi nasional dimana keberhasilan Komisi Kebenaran sebagian diperhitungkan dari 
Aulia Rosa Nasution, Penyelesaian Kasus Pelanggaran HAM Berat melalui Pengadilan Nasional dan Internasional serta Komisi Kebenaran dan Rekonsiliasi

seberapa besar kemampuan dan keberhasilannya menciptakan rekonsiliasi.

Pada pemerintahan pasca Soeharto telah dikelaurkan Tap V/ MPR/ 2000 dan UU No. 26 Tahun 2000 sebagai dasar hukum dari KKR di Indonesia. Dalam Bab I, huruf B, Paragraf kedua TAP MPR $\mathrm{V} / \mathrm{MPR} / 2000$ ditegaskan bahwa “ kesadaran dan komiten yang sungguhsungguh untuk memantapkan persatuan dan kesatuan nasional harus diwujudkan dalam langkah-langkah nyata, berupa pembentukan Komisi Kebenaran dan Rekonsiliasi Nasional serta merumuskan etika berbangsa dan visi Indonesia masa depan. Dalam bab $\mathrm{V}$ angka 3 juga ditegaskan bahwa"

...Komisi ini (KKR) bertugas untuk menegakkan kebenaran dengan mengungkapkan penyalahgunaan kekuasaan dan pelanggaran HAM pada masa lampau sesuai dengan huk dan peraturan perundang-undangan yagn berlaku serta melaksanakan rekonsiliasi dalam perspektif kepentingan bersama sebagai bangsa. Lebih jauh dalam bab itu juga ditegaska bahwa "langkah-langkah setelah pengungkapan kebenaran, dapat dilakukan melalui pengakuan kesalahan, permintaan maaf, pemberian maaf, perdamaian, penegakan hukum, amnesti, rehabilitasi, atau alternatif lain yang bermanfaat untuk menegakkan persatuan dan kesatuan bangsa dengan sepenuhnya memperhatikan rasa keadilan masyarakat".

Dalam kurun waktu empat tahun setelah disahkan UU No. 26 tahun 2000 tentang Pengadilan HAM, maka dikeluarkanlah UU No. 27 Tahun 2004 tentang Komisi Kebenaran dan
Rekonsiliasi setelah keluar mandat TAP MPR No. V/MPR/2000 dan UU N0. 26 Tahun 2000. Namun sayangnya pada 7 Desember 2006 atau dua tahun setelah diundangkan , UU KKR dibatalkan oleh MK melalui putusannya Nomor 006/puuIV/2006. MK memutuskan UU No.27 tahun 2004 tentang Komisi Kebenaran dan Rekonsiliasi (KKR) bertentangan dengan UUD 1945 . Karena itu KKR dinyatakan tidak mempunyai kekuatan hukum yang mengikat.

Sementara itu menurut hakim I Dewa Gede Palaguna yang mengemukakan pendapat yang berbeda (dissenting opinion), hanya pasal 27 (Kompensasi dan rehabilitasi sebagaimana dimaksudkan dalam pasal 19 dapat diberikan apabila permohonan amnesti dikabulkan) UU KKR yang bertentangan dengan UUD 1945 sedangkan Pasal 1 angka 9 (Amnesti adalah pengampunan yang diberikan oleh presiden kepada pelaku pelanggaran HAM yang berat dengan memerhatikan pertimbangan DPR) dan Pasal 44 (pelanggaran HAM yang berat yang telah diungkapkan dan diselesaikan oleh Komisi, perkaranya tidak dapat diajukan lagi kepada pengadilan HAM), sama sekali tidak bertentangan dengan UUD 1945. Pembatalan UU No. 27 Tahun 2004 tentang KKR ini juga akhirnya secara tidak langsung membatalkan terbentuknya anggota KKR yang mana proses seleksinya telah sampai ke tingkat Presiden, sekaligus memupus alternatif penyelesaian kasus pelanggaran HAM berat sebagaimana yang dimandatkan oleh UU No. 26 Tahun 2006. Meskipun UU tentang KKR ini telah dibatalkan menurut Jimly Asshidiqie, hal ini tidak berarti MK menutup upaya penyelesaian pelanggaran HAM berat di 
masa lalu melalui upaya rekonsiliasi. Dengan kata lain, upaya penyelasaian kasus pelanggaran.

\section{SIMPULAN}

Pelanggaran HAM Berat merupakan salah satu persoalan serius di dalam pemerintahan Indonesia dimana pemerintah telah berupaya menyelesaikan berbagai kasus pelanggaran HAM berat melalui instrument hukum yaitu Undangundang Nomor 39 tahun 1999 tentang HAM dan Undang-undang Nomor 26 tahun 2000 tentang Pengadilan HAM meskipun belum dapat berfungsi dan berjalan secara maksimal di dalam menyelesaikan kasus pelanggaran HAM berat yang terjadi di Indonesia.

Keberadaaan Pengadilan Pidana Internasional (International Criminal Court-ICC) dan juga beberapa Pengadilan Internasional ad - hoc lainnya mulai dari Pengadilan Internasional Nurenberg di Jerman, Mahkamah Militer Tokyo, Pengadilan Kejahatan Internasional untuk Rwanda, Pengadilan Kejahatan Internasional untuk negara-negara bekas Yugoslavia, dan Pengadilan Internasional Campuran telah menunjukkan bahwasanya tidak seorangpun dapat lari dari tanggungjawabnya terhadap tindakan pelanggaran HAM yang dilakukan dimana setiap orang memiliki kewajiban untuk mempertanggungjawabkan setiap bentuk pelanggaran berat HAM yang dilakukannya melalui mekanisme pengadilan.

\section{Mekanisme}

penyelesaian pelanggaran HAM berat melalui melalui mekanisme KKR dapat menjadi alternatif terbaik bagi suatu negara didalam upaya penyelesaian terhadap berbagai kasus - kasus pelanggaran HAM berat karenamampu mengungkap fakta atau kebenaran dan jalan pengadilan atas peristiwa pelanggaran HAM yang berat yang dilakukan oleh rezim pemerintahan yang lama serta dapat memutus politik impunitas dan mengantarkan rezim baru menuju sistem demokratis dan negara hukum sebagai sistem besar bagi tegaknya hak- hak asasi manusia.

\section{DAFTAR PUSTAKA}

Abdul Latif, Mahkamah Konstitusi Dalam Upaya Mewujudkan Negara Hukum Demokrasi, Total Media, Yogjakarta, 2007

A. Ubaedillah \& Abdul Rozak, Pendidikan Kewarganegaraan, Demokrasi , Hak Asasi Manusia dan Masyarakat Madani, Indonesian Center for Civic Education (ICCE), Kencana Prenada Media, Jakarta, 2008

Ahmad Kosasih , " HAM dalam Perspektif Islam ; Menyingkap Persamaan dan Perbedaan antara Islam dan Barat", Jakarta: Salemba Diniyyah, Edisi Pertama, 2003

Bambang Sutiyoso, Reformasi Keadilan dan Penegakan Hukum di Indonesia, UII Press, Yogjakarta, 2010

Bur Rasuanto, Keadilan Sosial Pandangan Deontologis, Rawls dan Habermas Dua Teori Filsafat Politik Modern, Gramedia Pustaka Utama, 2005

Eddy, O.S., Hiariej, "Pengadilan atas Beberapa Kejahatan Serius terhadap HAM, Jakarta: Erlangga 2010

Endang Sutrisno, Bunga Rampai Hukum \& Globalisasi, Genta Press, Yogjakarta, 2007

Hamid Awaluddin, "HAM Politik, Hukum, dan Kemunafikan Internasional”, Jakarta: Buku Kompas, 2012

H.A.R, Tilaar ,Perubahan Sosial dan Pendidikan: Pengantar Pedagogi Transformatif untuk Indonesia, PT Grasindo , Jakarta, 2002

Iman Santosa," Hukum Pidana Internasional",Bandung: Pustaka Reka Cipta, 2013

Max Boli Sabon, Hak Asasi Manusia Bahan Pendidikan Untuk Perguruan Tinggi, Universitas Atma Jaya , 2014

Majda El Muhtaj, Hak Asasi Manusia dalam Konstitusi Indonesia Dari UUD 1945 sampai dengan Amandemen UUD 1945 Tahun 2002, 
Aulia Rosa Nasution, Penyelesaian Kasus Pelanggaran HAM Berat melalui Pengadilan Nasional dan Internasional serta Komisi Kebenaran dan Rekonsiliasi

(Jakarta: Kencana Prenada Media, Cetakan ke-3, 2005

Masyhur Effendi, Perkembangan Dimensi Hak Asasi Manusia (HAM), dan Proses Dinamika Penyusunan Hukum Hak Asasi Manusia (HAKHAM), Ghalia Indonesia,2006

Romli Atmasasmita, "Reformasi Hukum, Hak Asasi Manusia dan Penegakan Hukum", Bandung: Mandar Maju, 2001

R. Wiyono, "Pengadilan Hak Asasi Manusia di Indonesia", Jakarta: Kencana Prenada Media, 2006

Sacipto Rahardjo, "Hak Asasi Manusia Dalam Masyarakat, dalam Muladi, Hak Asasi Manusia , Hakikat, Konsep dan Implikasinya dalam Perspektif Hukum dan Masyarakat", Bandung: Refika Aditama, 2005

Scott Davidson, Hak Asasi Manusia, Pustaka Utama Grafiti, 2008

Syawal Abdulajid \& Anshar, "Pertanggungjawaban Pidana Komando Militer Pada Pelanggaran Berat HAM" (Suatu Kajian Dalam Teori Pembaharuan Pidana), Yogjakarta: LaksBang PRESSindo

Suparman Marzuki, " Robohnya Keadilan! Politik Hukum HAM Era Reformasi ", Yogjakarta: PUSHAM-UII, 2010

Zamroni, Pendidikan untuk Demokrasi: Tantangan Menuju Civil Society, Yogjakarta, BIGRAF Publishing, 2001

Undang- Undang Nomor 39 Tahun 1999 tentang Hak Asasi Manusia 